UNIVERSIDADE DE SÃO PAULO

FACULDADE DE ECONOMIA, ADMINISTRAÇÃO E CONTABILIDADE

DEPARTAMENTO DE ECONOMIA

PROGRAMA DE PÓS-GRADUAÇÃO EM ECONOMIA

\title{
Compulsory Voting and TV News
}

\section{Consumption: Evidence from Brazil}

Voto obrigatório e consumo de informação no Brasil

Raphael Guinâncio Bruce

Orientador: Prof. Dr. Rafael Coutinho Costa Lima

São Paulo - Brasil

2015 
Prof. Dr. Marco Antonio Zago

Reitor da Universidade de São Paulo

Prof. Dr. Adalberto Américo Fischmann

Diretor da Faculdade de Economia, Administração e Contabilidade

Prof. Dr. Hélio Nogueira da Cruz

Chefe do Departamento de Economia

Prof. Dr. Márcio Issao Nakane

Coordenador do Programa de Pós-Graduação em Economia 


\title{
RAPHAEL GUINÂNCIO BRUCE
}

\section{Compulsory Voting and TV News}

\section{Consumption: Evidence from Brazil}

Voto obrigatório e consumo de informação no Brasil

\author{
Dissertação apresentada ao Depar- \\ tamento de Economia da Faculdade \\ de Economia, Administração e Con- \\ tabilidade da Universidade de São \\ Paulo como requisito parcial para a ob- \\ tenção do título de Mestre em Ciências.
}

Orientador: Prof. Dr. Rafael Coutinho Costa Lima

Versão Original

São Paulo - Brasil

2015 
FICHA CATALOGRÁFICA

Elaborada pela Seção de Processamento Técnico do SBD/FEA/USP

Bruce, Raphael Guinâncio

Compulsory voting and TV news consumption: evidence from Brazil /

Raphael Guinâncio Bruce. -- São Paulo, 2015.

$66 \mathrm{p}$.

Dissertação (Mestrado) - Universidade de São Paulo, 2015.

Orientador: Rafael Coutinho Costa Lima.

1. Voto obrigatório 2. Regressão em descontinuidade 3. Mídia 4. Informação I. Universidade de São Paulo. Faculdade de Economia, Administração e Contabilidade. II. Título.

$$
\text { CDD - } 324
$$




\section{Agradecimentos}

Aos meus pais, pelo carinho e apoio incondicional desde Novembro de 1988.

À Graziella, minha companheira de todas as horas durante essa longa jornada e por muitas outras que virão.

Ao meu orientador Rafael Costa Lima pela atenção, disponibilidade e, principalmente, pelo exemplo de bom profissional dentro da academia.

Ao professor Filipe Campante pela generosidade intelectual e apoio constante durante sua coorientação por seis meses em Cambridge. Ao professor Thomas Fujiwara pelos comentários feitos em versões anteriores desse trabalho em reuniões e apresentações durante minha estada no exterior. Aos professores da FEA-USP Fernanda Estevan, Marcos Nakaguma, Mauro Rodrigues e Raphael Corbi pelas sugestões.

Aos colegas Ana Paula Melo, Beatriz Garcia, Caio Costa, Daniel Dantas, Danilo Souza, Fernando Carnaúba, Gabriel Corrêa, Leonardo Rosa, Leonardo Viotti, Luiza Andrade, Maurício Matsumoto, Pedro Forquesato, Pedro Schneider, Radamés Marques, Rafael Tavares, Samuel Godoy e Tales Rozenfeld, pelas conversas, conselhos e pelos constantes momentos de alegria que pontuaram o calendário intenso que iniciou em 2013 e se encerra agora.

Finalmente, à Fundação de Amparo à Pesquisa de São Paulo (FAPESP), ao Conselho Nacional de Pesquisa Científica (CNPq) e à Coordenação de Aperfeiçoamento de Pessoal de Nivel Superior (CAPES) que me apoiaram financeiramente em diferentes fases do mestrado. 



\section{Resumo}

Pessoas que são obrigadas a votar procuram fazer isso de maneira informada? Essa dissertação procura saber se a lei de voto obrigatório brasileira induz eleitores a consumirem mais informação via noticíarios televisivos. Mais especificamente, procuramos saber se o consumo de informações via o noticiário Jornal Nacional, transmitido pela Rede Globo, aumenta em decorrência da exposição à lei. No Brasil, todo cidadão alfabetizado com idade maior que dezoito e menor que setenta anos está sujeito a uma série de punições caso se abstenha sem justificativa nas eleições. Isso gera um experimento natural que nos permite utilizar a técnica de regressão descontínua para recuperar o efeito causal dessa lei sobre o consumo de informação por parte dos eleitores. Encontramos um aumento de 10,4\% na probabilidade do eleitor jovem assistir o programa Jornal Nacional que pode ser atribuído especificamente ao fato desse cidadão ser obrigado a votar. Nenhum efeito é encontrado para cidadãos que deixam de ser obrigados aos setenta anos de idade.

Palavras-chaves: Voto obrigatório, Regressão em descontinuidade, Mídia, Informação. 



\begin{abstract}
Do people acquire more information when they are obligated to participate in elections? This dissertation presents empirical evidence on the effects of compulsory voting laws on the consumption of TV news. In Brazil, the law determines that every literate citizen over the age of eighteen and under seventy at the day of the election is subject to a number of penalties if they don't attend the ballots. This provides a natural experiment which allows us to identify the causal effect of being under a compulsory voting regime on information acquisition. Using national survey data on the consumption of media we find that, for those who have been exposed to the law for the first time, compulsory voting has a significant and substantial positive impact on the probability of an individual to watch Brazil's main newscast, Rede Globo's Jornal Nacional. No impact is found, though, for citizens who transition from the voluntary to the compulsory voting regime when they reach the age of seventy.
\end{abstract}

Key-words: Compulsory voting, Regression discontinuity design, Media, Information. 



\section{Sumário}

1 Introduction . . . . . . . . . . . . . . . 13

2 Theoretical Framework . . . . . . . . . . . . . . 17

2.1 Benchmark model . . . . . . . . . . . . . . . . . . . 17

2.2 Introducing Compulsory Voting . . . . . . . . . . . . . 22

3 Institutional Background . . . . . . . . . . . 25

3.1 The Compulsory Voting Law . . . . . . . . . . . . . . . 25

3.2 Rede Globo and Jornal Nacional . . . . . . . . . . . . . . 26

4 Data and Research Design . . . . . . . . . . . . . . . 29

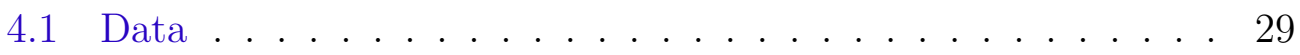

4.2 Identification Strategy . . . . . . . . . . . . . . . 30

5 Results ........................ 35

6 Robustness ....................... 39

7 Concluding Remarks . . . . . . . . . . . . . . . . . . . 43

Referências ..................... . . 45

Apêndice A . . . . . . . . . . . . . . . . . . . 47 



\section{Introduction}

In his 1996 Presidential Address to the American Political Science Association, Arend Lijphart defended compulsory voting laws as a way to solve the problem of unequal political participation in elections. He argued that penalizing abstention would have three consequences on the electorate: an increase in turnout, an increase in political knowledge, and an increase in political engagement Lijphart (1997). Our interest in this dissertation is related to the last two effects. More specifically, we study how inducing turnout through compulsory voting affects information acquisition.

The Brazilian electoral law determines that every literate citizen above eighteen and younger than seventy by the day of the elections is subject to a number of penalties in case she fails to attend an official polling station and cast a ballot. These two discontinuities in the enforcement of the law enable us to measure the causal effect of compulsory voting on the consumption of TV newscasts. Using novel data on media-related habits of the Brazilian population, we find that, for those who are being exposed to the penalties for their first time at the eighteen, there is a $10.4 \%$ increase in the probability to watch Rede Globo's Jornal Nacional, Brazil's most trusted newscast. No impact is found, though, for elderly voters at the second discontinuity who are transitioning into a voluntary voting regime when they reach the age of seventy. We show that this increase in the consumption of TV news for young voters restricted to Jornal Nacional. Our results are robust to different polynomial orders and bandwidth lengths. 
The fact that voters, when induced to take part in the electoral process, choose Jornal Nacional over any other newscast in order to become more informed highlights the role credibility plays when it comes to information acquisition. ${ }^{1}$ With an audience share of $70 \%$, the equivalent to 31 million viewers, Jornal Nacional is the most watched newscast in Brazilian television. On air from Monday to Saturday at 8:30 pm, it premiered on September 1, 1969, and since then has become a daily presence in the life of Brazilian families. According to Porto (2007), almost half of its length focuses on political, economic and social themes, making it a natural source of information for typically salient issues for voters.

Most of the existing evidence regarding compulsory voting and information acquisition is still mixed, and relies mostly on cross-country comparisons or laboratory experiments. Using data from the 1989 Euro-Barometer postelection survey, Gordon \& Segura (1997) measure the political sophistication of each respondent in the twelve nations of the pre-1995 European Union. They find a positive correlation between the presence of compulsory voting legislation and political sophistication. Grosser, Seebauer et al. (2008) find that participants in a laboratory experiment mode are more likely to acquire costly information when not given the option to abstain from elections. On the other hand, Loewen, Milner \& Hicks (2008) and Birch (2009) find no evidence on the relation between being under compulsory voting and being

1 There's a still small but growing literature on the how the credibility of sources shapes the way voters process and acquire information. Chiang \& Knight (2011) show how the impact of newspaper endorsements on voter's opinion varies with the degree and the direction of bias of the endorser. Alt, Lassen \& Marshall (2014) find that economic information acquired from the Danish Central Bank causes voters to update their belief more than receiving information from the government or political parties. 
more informed.

One exception which provides within-country evidence is Leon \& Rizzi (2014). The authors focus on the impact of compulsory voting on information about strictly political issues, such as names of candidates and knowledge about platforms. Using a self-conducted survey restricted to a few schools in the metropolitan area of the city of São Paulo, Brazil, and to freshmen students at the University of São Paulo, a highly selective public university, the authors find that the increase in turnout as a consequence of the compulsory voting is not followed by an increase in the consumption of political information. This dissertation differs by using nationally representative data which does not restrict our analysis to a specific level of education or a specific age range. By focusing on TV news consumption, we are also able to meausure the impact of the compulsory voting law on information acquisition on other issues besides politics that might be salient to voters, such as the state of the economy, urban violence, health and education policy.

This dissertation also contributes to the growing literature that studies the relation between the media and political outcomes. More specifically, by asking what is the impact of turnout on media consumption, we reverse the research question from Gentzkow (2006) and DellaVigna \& Kaplan (2007). On the first paper, the author shows how the introduction of television in different markets decreased turnout and political knowledge. On the second paper the authors examine how the expansion of the conservative Fox News Channel increased voter turnout and the Republican vote share on US elections.

The remainder of the dissertation is organized as follows. Chapter II 
presents a theoretical framework that links mandatory voting to information acquistion. Chapter III provides some basic background information on the mandatory voting law in Brazil and on Jornal Nacional, and Chapter IV describes the data and our empirical strategy. The results are presented in Chapter V, followed by robustness checks and placebo tests in Chapter VI. Section VII concludes the paper. 


\section{Theoretical Framework}

\subsection{Benchmark model}

Our model follows closely the uncertain-voter model proposed by Degan (2006), who studies the relationship between policy preferences, turnout and information acquisition. Similar to León (2015), we expand the model to analyze how compulsion affects voters preferences and turnout decisions. We take it one step further and also show how compulsion ultimately affects information acquisition.

In our set-up there are two candidates $c \in\{L, R\}$, each one running on a platform $y_{c} \in Y_{c} \subset Y$, where $Y$ is the left-right policy space. Citizens are distributed across a continuum of measure 1 , and each citizen $j$ has a preferred platform $y_{j} \in Y$. They evaluate each candidate according to the following payoff function:

$$
u_{j}^{C}=-\left(y_{j}-y_{c}\right)^{2} .
$$

Citizens are also uncertain about the platforms chosen by candidates, which, from their perspective, are random variables $\left(\tilde{y}_{L}, \tilde{y}_{R}\right)$ following a distribution $F$ on $Y_{L} \times Y_{R}$. For the sake of simplicity, we assume that $Y_{L}=$ $[-1,0]$ and $Y_{R}=[0,1]$ and that $F($.$) is symmetric around zero.$

Citizen $j$ has an information set $\Omega_{j} \in \Omega=\left\{F,\left(y_{L}, y_{R}\right)\right\}$, which is the the main source of heterogeneity between voters. If a voter is uninformed 
he makes decisions based on the distribution $F$. In case she has information about the candidates, $\Omega_{j}=\left(y_{L}, y_{R}\right)$. Information is costly and can be acquired by incurring in a cost $\delta>0$. The dummy $i_{j} \in\{0,1\}$ captures the citizen's decision of whether or not to invest in information. Those who invest will be able to observe the true platforms with probability $p \in(0,1]$. Otherwise, they will have to make an uninformed decision based on $F$.

Central to the model is the idea that this uncertainty about the candidates' platforms generates a disutility from making voting mistakes. In particular, the behavioral cost of voting for candidate $L$ is defined as the expected utility loss generated by the possibility of voting for this candidate by mistake, given by $^{1}$ :

$$
C_{j}\left(L ; y_{j}, \Omega_{j}\right)=\mathbb{E}\left[\mathbf{1}\left\{u_{j}^{L}<u_{j}^{R}\right\} \cdot\left(u_{j}^{R}-u_{j}^{L}\right) \mid \Omega_{i}\right]
$$

When the individual is not certain about the position of each candidate on the policy space they can always incur on a positive cost $C_{j}() \geq$.0 . Those who have successfully acquired information about the candidates' platform can always pick the correct candidate and obtain $C_{j}()=$.0 . Every citizen also has a civic-duty benefit $d_{j} \geq 0$ from attending the ballots at they day of the election.

The citizen's decision making process can be seen as a three step problem. In the first stage she must choose whether or not to acquire information. Next, given her information set, she chooses whether or not to turn out to

\footnotetext{
1 The case for $R$ is symmetric.
} 
vote. Lastly, the voter must decide on whom to vote for. The optimization problem faced by the citizen is:

$$
\max _{v_{j}, t_{j}, i_{j}} t_{j}\left[d_{j}-C_{j}\left(v_{j} ; y_{j}, \Omega_{j}\right)\right]-\delta \cdot i_{j}
$$

The solution to this problem can be found by solving the model backwards and is given by the tuple $\left(v_{j}^{*}, t_{j}^{*}, i_{j}^{*}\right)$. We start by the voting decision. In this stage, citizen $j$ must choose between $L$ and $R$ according to the following voting rule:

$$
v^{*}\left(y_{j}, \Omega_{j}\right)= \begin{cases}L, & \text { if } C_{j}\left(L ; y_{j}, \Omega_{j}\right)<C_{j}\left(R ; y_{j}, \Omega_{j}\right) \\ R, & \text { if } C_{j}\left(R ; y_{j}, \Omega_{j}\right)<C_{j}\left(L ; y_{j}, \Omega_{j}\right)\end{cases}
$$

If $C_{j}\left(R ; y_{j}, \Omega_{j}\right)=C_{j}\left(L ; y_{j}, \Omega_{j}\right)$, the agent randomizes. Saying that $j$ votes for $L$ if and only if $C_{j}\left(L ; y_{j}, \Omega_{j}\right)-C_{j}\left(R ; y_{j}, \Omega_{j}\right)<0$ is equivalent to saying that she votes for $L$ if and only if $\mathbb{E}\left[\left(u_{j}^{L}-u_{j}^{R}\right) \mid \Omega_{j}\right]>0$. Substituting the citizen's utility function into this last inequality and making the condition binding gives the ideological cutoff point $\tau\left(\Omega_{J}\right)=\frac{\mathbb{E}\left[\left(y_{R}^{2}-y_{L}^{2}\right) \mid \Omega_{j}\right]}{2 \mathbb{E}\left[\left(y_{R}-y_{L}\right) \mid \Omega_{j}\right]}$.

Next, we proceed to the turnout decision. Given that $C_{j}\left(y_{j}, \Omega_{j}\right) \equiv$ $C_{j}\left(v_{j}^{*}\left(y_{j}, \Omega_{j}\right)\right)$, citizen $j$ chooses whether to turn out or not in the day of the 
election according to the following cutoff rule:

$$
t^{*}\left(y_{j}, \Omega_{j}\right)= \begin{cases}1, & \text { if } C_{j}\left(v_{j}^{*}\left(y_{j}, \Omega_{j}\right)\right)-d_{j}>0 \\ 0, & \text { if } C_{j}\left(v_{j}^{*}\left(y_{j}, \Omega_{j}\right)\right)-d_{j} \geq 0\end{cases}
$$

Therefore, if the net benefit of casting a ballot (i.e. the opportunity cost of abstention) is positive, citizen $j$ will turnout, otherwise he will stay at home. The last step in the optimization problem is the one where the citizen must decide whether or not to acquire information. In this step, the voter compares the benefit he derives from voting against the real cost of becoming more informed, given by $\frac{\delta}{p}$. The decision to become or not more informed is given by:

$$
i^{*}\left(d_{j}, \delta, p\right)= \begin{cases}1, & \text { if } d_{j}>\frac{\delta}{p} \\ 0, & \text { if } d_{j} \leq \frac{\delta}{p}\end{cases}
$$

Note that there can be four different kinds of voters: they can either turnout or not, and can either acquire information or not. Suppose $d_{j} \geq \frac{d_{j}}{p}$. When $C_{j}\left(v_{j}^{*}\left(y_{j}, \Omega_{j}\right)\right)>d_{j}$ the individual will abstain and obtain a payoff equal to zero. Therefore, she will acquire information because $d_{j} p-\delta \geq 0$. When $d_{j} \geq C_{j}\left(v_{j}^{*}\left(y_{j}, \Omega_{j}\right)\right)$, an individual will acquire information if $d_{j}-$ $C_{j}\left(v_{j}^{*}\left(y_{j}, \Omega_{j}\right)\right)(1-p)-\delta \geq d_{j}-C_{j}\left(v_{j}^{*}\left(y_{j}, \Omega_{j}\right)\right)$. This implies that voters who turnout will obtain information if the behavioral cost of casting a vote for the wrong candidate is larger than the real cost of becoming informed, 
i.e., if $C_{j}\left(v_{j}^{*}\left(y_{j}, \Omega_{j}\right)\right) \geq \frac{\delta}{p}$. Finally, when $d_{j}<\frac{d_{j}}{p}$, citizens will never acquire information but will turnout if $d_{j} \geq C_{j}\left(v_{j}^{*}\left(y_{j}, \Omega_{j}\right)\right)$. The main results from the model can be summarized in the following proposition.

Proposition 2.1.1. (Degan (1996)) Given the information set $\Omega_{j} \in \Omega$ :

1. Conditional on voting, maximizing the net benefit of voting is equivalent to voting for the candidate who generates the highest expected relative payoff. This means that $v_{j}^{*}=L$ if, and only if, $\mathbb{E}\left[\left(u_{j}^{L}-u_{j}^{R}\right) \mid \Omega_{j}\right]>0$ and $v_{j}^{*}=R$ if, and only if, $\mathbb{E}\left[\left(u_{j}^{R}-u_{j}^{L}\right) \mid \Omega_{j}\right]>0$.

2. The ideological cutoff which determines the optimal voting rule is given by $\tau\left(\Omega_{J}\right)=\frac{\mathbb{E}\left[\left(y_{R}^{2}-y_{L}^{2}\right) \mid \Omega_{j}\right]}{2 \mathbb{E}\left[\left(y_{R}-y_{L}\right) \mid \Omega_{j}\right]}$. The optimal voting rule is completely specified by $y_{j}$ and $\tau\left(\Omega_{j}\right)$ : citizens either vote for $L$ if, and only if, $y_{j}<\tau\left(\Omega_{j}\right)$, or for $R$ if, and only if, $y_{j}>\tau\left(\Omega_{j}\right)$. Note that if $\Omega_{j}=\left(y_{L}, y_{R}\right), \tau\left(\Omega_{j}\right)=$ $\frac{y_{R}+y_{L}}{2}$, and if $\Omega_{j}=F, \tau\left(\Omega_{j}\right)=0$.

3. The cost of voting $C_{j}\left(v_{j}^{*} ; y_{j}, \Omega_{j}\right)$ is single peaked at 0 for all values of $y_{j}$ subject to $\left|y_{j}\right|>\frac{1}{2}$ and $C_{j}\left(v_{j}^{*} ; y_{j}, \Omega_{j}\right)=0$ for all $\left|y_{j}\right| \geq \frac{1}{2}$.

4. For all $x \in(0, \bar{C}]$, where $\bar{C}=\max _{j} C_{j}\left(v_{j}^{*} ; y_{j}, \Omega_{j}\right)$, let $l(x) \in Y_{L}$ and $r(x) \in Y_{R}, l(x)=-r(x)$ be the points in the policy space such that when $y_{k} \in\{l(x), r(x)\}$ then $C_{k}^{*}()=$.$x . Individuals can be either partisan$ (strong or weak) or middle-of-the-road voters. Partisans belong to $N_{d}^{P}=$ $\left\{j: y_{j} \in Y \backslash\left[l\left(d_{j}\right), r\left(d_{j}\right)\right]\right.$ and middle-of-the-road belong to $N_{d}^{R}=\{j:$ $y_{j} \in\left[l\left(d_{j}\right), r\left(d_{j}\right)\right]$. Weak partisans are those who belong to $N_{d}^{W}=\{j:$ $\left.y_{j} \in\left[l\left(\frac{\delta}{p}\right), l\left(d_{j}\right)\right] \cup\left[r\left(d_{j}\right), r\left(\frac{\delta}{p}\right)\right], d_{j}>\frac{\delta}{p}\right\}$ and strong partisans belong 
to $N_{d}^{S}=N_{d}^{P} \backslash N_{d}^{W}$. We have that: (i) when $d_{j} \geq \frac{\delta}{p}$, if $j \in N_{d}^{S}$, then $i^{*}\left(d_{j}, \delta, p\right)=1$, otherwise $i^{*}\left(d_{j}, \delta, p\right)=0 ;$ (ii) for $d_{j}<\frac{\delta}{p}, i^{*}\left(d_{j}, \delta, p\right)=0$ independent of $y_{j}$, and; (iii) for $j \in N_{d}^{P}$, we always have that $t^{*}\left(y_{j}, \Omega_{j}\right)=$ 1, while for $j \in N_{d}^{W}, t^{*}\left(y_{j}, \Omega_{j}\right)=1$ if and only if $i^{*}\left(d_{j}, \delta, p\right)=1$.

Proof. See Degan (2006).

Mind that both strong and weak partisans vote, but only the latter acquire more information. Those at the middle-of-the-road group acquire information whenever it is not too costly and vote only if they successfully discover the candidates' position on the policy space.

We are interested in analyzing the effects of compulsory voting laws on the decision to become more informed. In order to do so, we must include in our benchmark model the abstention penalties that citizens must face when they fail to turnout.

\subsection{Introducing Compulsory Voting}

Under compulsory voting, citizens must now incur in a cost $M$ if they wish to abstain. The modified optimization problem is given by:

$$
\max _{v_{j}, t_{j}, i_{j}} t_{j}\left[d_{j}-C_{j}\left(v_{j} ; y_{j}, \Omega_{j}\right)\right]-\left(1-t_{j}\right) M-\delta \cdot i_{j}
$$

Which can be rewritten as: 


$$
\max _{v_{j}, t_{j}, i_{j}} t_{j}\left[\hat{d}_{j}-C_{j}\left(v_{j} ; y_{j}, \Omega_{j}\right)\right]-M-\delta \cdot i_{j}
$$

where $\hat{d}_{j}=d_{j}+M$ is the induced benefit from attending the ballots and $\hat{d}_{j}-C_{j}\left(v_{j} ; y_{j}, \Omega_{j}\right)$ is the opportunity cost of abstention under compulsory voting. The solution to this problem, as in our benchmark set-up, can be found by solving the model backwards.

Proposition 2.2.1. Let $M>0$ and $\hat{d}_{j}=d_{j}+M$. Under compulsory voting the equilibrium characterized by the Results 1-3 on Proposition 2.1.1 hold. Furthermore, compulsion leads to an increase in turnout for every citizen $j$ with $\hat{d}_{j}>C_{j}\left(v_{j} ; y_{j}, \Omega_{j}\right) \geq d_{j}$ and an increase in the investment information for those with $\hat{d}_{j}>\frac{\delta}{p} \geq d_{j}$.

Proof. The first three results on Proposition 2.1.1 are independent from $d_{j}$, and, therefore, not affected by the introduction of $M$. Both turnout and information acquisition changes caused by compulsory voting follow from Equation 2.8 and Equation 2.6, respectively.

Compulsory voting also leads to changes on the composition of the electorate. For the sake of simplicity, suppose $d_{j}=d$ for all $j$, i.e. the only source of heterogeneity in the population is the distribution of $C_{j}\left(v_{j} ; y_{j}, \Omega_{j}\right)$. With $d>\frac{\delta}{p}$, compulsory voting leads to an increase in the number of weak partisans and reduces the number of middle-of-the-road voters by the same amount. On the other hand, if $d \leq \frac{\delta}{p}$, compulsion will only affect the size of 
the groups if $\hat{d}>\frac{\delta}{p}$. On both cases, strong partisans are never affected by compulsion.

Since all partisans turnout to vote independent of their information, strong partisan voters never invest in becoming more informed and, since $N_{d}^{W}=\emptyset$ if $d \leq \frac{\delta}{p}$, only middle-of-the-road citizens will have their investment decision changed by the compulsory voting law. Moreover, from the fact that $\hat{d}>d$, we have $N_{\hat{d}}^{R}=\left\{j: y_{j} \in[l(\hat{d}), r(\hat{d})] \supset N_{d}^{R}\right.$ and $N_{\hat{d}}^{W}=\{j:$ $\left.y_{j} \in\left[l\left(\frac{\delta}{p}\right), l(\hat{d})\right] \cup\left[r(\hat{d}), r\left(\frac{\delta}{p}\right)\right], d>\frac{\delta}{p}\right\} \subset N_{d}^{W}$. This means that the group of middle-of-the-road voters is smaller and the group of weak partisans is larger when abstention penalties are introduced. Therefore, the model predicts that compulsion will lead nonpartisan voters who would not turnout otherwise to turnout and invest in information. 


\section{Institutional Background}

\subsection{The Compulsory Voting Law}

Brazil's current compulsory voting legislation started with the promulgation of the Brazilian Constitution of 1988. It states that every literate citizen older than 18 and younger than 70 years old must attend the ballots on election day or justify its absence in a special court. Citizens older than 16 and younger than 18 are allowed to register to vote, but do not face any consequence if they don't. ${ }^{1}$ If an individual fails to justify her absence, she must pay a small fine of $\mathrm{R} \$ 3.00$ (roughly 1.15 dollars), which can be multiplied tenfold according to the decision of the judge handling the case. Those who fail to justify three times are also subject to a number of sanctions, such as not being allowed to issue a new ID or a new passport, being ineligible for cash transfer programs, credit by financial institutions maintained by the government, public jobs and public education. ${ }^{2}$

The abstention rates in Brazil are also low. For example, in the 2012 elections the average abstention in Brazilian municipalities was 14\%, with $9 \%$ invalid votes cast for mayor and $5 \%$ invalid votes for city council. This leads us to believe that the law is indeed enforced and turnout is high in the presence of compulsory voting. Recent research by Cepaluni \& Hidalgo (2015) using the full Brazilian voter file comprising of 140 million individuals shows

1 According to the Superior Electoral Court of Brazil (TSE), only one fourth of individuals under eighteen years registered to vote in the 2014 elections.

2 For more information, see http://www.tse.jus.br/eleitor/servicos/justificativa-eleitoral (in Portuguese). 
that Brazilian compulsory voting law has a sizable causal impact on turnout, in line with the findings of Leon \& Rizzi (2014).

\subsection{Rede Globo and Jornal Nacional}

Television plays a major role in the life of brazilian citizens. According to the 2006 National Household Sample Survey (PNAD), 93\% of the households owned at least one television set, and, according to the Brazilian Media Survey of 2014, a vast majority of the population has the TV as their main source of information, as it can be seen in Figure A.1. Owned by Globo Organization, a conglomerate founded by media mogul Roberto Marinho, Rede Globo was launched in 1965, amidst Brazil's military regime. Since then it quickly expanded to become the leading TV network in the country.

According to Ferrara, Chong \& Duryea (2012), Rede Globo's swift growth started during the military dictatorship as a consequence of the central authority's ambition to integrate the country using mass media. The government saw in television the potential to promote a sense of national identity and, thus, encouraged its expansion. This was done by subsidizing credit for set sales and by granting concessions following clientelistic and political criteria, a process from which Globo took great advantage. It has since been regarded as the the most powerful television network in Brazil, with 35 affiliated networks and over 3305 retransmission stations that enable Globo's TV signal to reach $98.56 \%$ of municipalities and $99.51 \%$ of the population. ${ }^{3}$

3 For more information see http://donosdamidia.com.br/rede/4023 and http://comercial2.redeglobo.com.br/atlasdecobertura/Paginas/Totalizador.aspx 
In a country where most people have access to television, Globo's presence in the everyday life of Brazilian citizens cannot be overstated.

Its flagship newscast is Jornal Nacional. On air from Monday to Saturday at 8:30 pm, it holds almost $70 \%$ of the TV share in its time slot, the equivalent to 31 million viewers, an impressive number when compared to similar news programs from Europe and North America (MESQUITA, 2010). ${ }^{4}$ According to the Brazilian Media Survey of 2014, it is also the most trusted newscast in Brazilian television, as Figure A.2 shows.

Both the consolidation of Brazilian democracy in the 90's and the many changes that happened in Rede Globo's News Division helped to shape the current format of Jornal Nacional. According to Porto (2007), during the last two decades about $40 \%$ of the length of the newscast is dedicated to political, social and economic related issues. The author also argues that the newscast has greatly reduced its reliance on official sources, a sign of its departure from its authoritarian roots.

(both in Portuguese).

4 For the sake of comparison, Mesquita (2010) notes that NBC Nightly News, America's most watched newscast, has an audience share of $15 \%$, BBC's Six O'Clock News has a share of $26 \%$ and TF1's 20 Heures from France has $46 \%$ of the audience share. 



\section{Data and Research Design}

\subsection{Data}

Our data comes from the first two waves of the Brazilian Media Survey (BMS). This is a nationally representative survey planned jointly by the Secretariat of Social Communication of the Brazilian Presidency (SECOM) and the Brazilian Institute of Public Opinion and Statistics (IBOPE). Its first wave, the BMS 2014, was implemented between October 12 and November 6, 2013, while its second wave, the BMS 2015, was implemented between November 5 and November 22, 2014. A total of 36624 citizens in 848 municipalities were interviewed face-to-face about their media consumption habits. According to the official release, the main objective of this survey was to map these habits in order to help the government improve the advertisement of policies that may fail to reach their main population of interest.

We should also consider the timing of the surveys with respect to the elections. The first round of the 2012 Local Elections took place on October 7 of that same year. On this day, citizens from all the 5568 municipalities of Brazil chose their mayors, members of the city council and members of the local legislative assemblies. One year after that, and one year prior to the national elections, the first wave of the BMS was implemented. The second wave of the BMS was implemented just one month after citizens attended the ballots to elect their congressmen, senators, state governors and the president. Since the registration deadline for the 2014 elections was at October 5, 2013, by the time both surveys were implemented all the candidates running on 
the national race had been officially announced. The timeline in Figure A.3 helps to understand how the timing of the Brazilian Media Survey relates to the local and federal elections.

In order to assure that the sample was representative, data from the 2010 National Census and the 2011 National Household Sample Survey were used. In the first stage of the sampling procedure, municipalities were randomly selected using probability proportional to size (PPS) sampling on the population older than 16 years old. Next, within each selected municipality, census tracts were selected using PPS once again. In the last step, individuals were chosen following proportional quotas on gender, race, age, education and activity.

\subsection{Identification Strategy}

Our focus is to evaluate the impact of the Brazilian compulsory voting law on the consumption of Jornal Nacional, Rede Globo's main newscast. We exploit the credibly exogenous source of variation of political participation which comes from the compulsory voting law in Brazil in order to provide results which can be interpreted as causal. As previously mentioned, the cost of abstention in Brazilian elections is a deterministic and discontinuous function of the age of the individual, enabling the use of a sharp regression discontinuity design (RDD) approach.

Similar to Leon \& Rizzi (2014), we compare individuals whose ages are in the neighborhood of the threshold that determines the change from 
voluntary voting to compulsory voting. Following Lee \& Lemieux (2010) we run an OLS on both sides of the threshold and compare the predicted value of their dependent variable at the discontinuity. We do so by estimating the following equation:

$$
Y_{i}=\alpha+\beta_{k} M_{i}+f\left(A_{i}-k\right)+\epsilon_{i}
$$

where $M_{i}$ is a dummy which indicates whether individual $i$ is exposed to compulsory voting $\left(M_{i}=1\right)$ or not $\left(M_{i}=0\right), A_{i}$ is the centered age of individual $i$ in months in the elections of October 2014, $k \in\{18,70\}$ is the age cutoff set by the law, and $f($.$) are continuous functions of our running$ variable centered at the cutoff value. The parameter of interest is $\beta$, the causal effect on $Y_{i}$ of being exposed to compulsory voting. We estimate our equation assuming that $f($.$) is a flexible polynomial on both sides of the$ threshold. We also take into account sampling weights in order to make the sample representative of Brazilian population. The forcing variable $A_{i}$ takes negative values for individuals with $M_{i}=0$ and positive values for citizens with $M_{i}=1 .^{1}$ The population around the 18 th birthday and the 70 th birthday at the October 2014 cutoff is made of those who were born at October, 1996 and October, 1944 respectively. This means that, for young voters changing from a voluntary voting to a mandatory voting regime at the 18th birthday cutoff, those who were born in November 1996 will have $A_{i}=-1$ and $M_{i}=0$,

$1 \quad$ Although sampling was done on a census tract level, the most granular geographical unit by which we can identify each individual is the state they were living in at the time the survey was implemented. 
and those born in September 1996 will have $A_{i}=1$ and $M_{i}=1$. For elderly voters around the 70th birthday cutoff, those born in November 1944 will have $A_{i}=1$ and $M_{i}=1$ and those born in September 1944 will have $A_{i}=-1$ and $M_{i}=0$.

Because we only have the month and the year of birth for each individual, additional care must be taken in order to reduce bias that may arise due to the few mass points of our running variable around the threshold. In order to deal with this problem, we cluster standard errors on our running variable in order to generate wider confidence intervals that reflect the imperfect fit of the parametric function away from the threshold (LEE; CARD, 2008). Furthermore, we follow Gelman \& Imbens (2014) and estimate only local linear and quadratic polynomials for different bandwidths. ${ }^{2}$

In order to identify $\beta$ as a causal parameter, our design must satisfy two key assumptions. The first states that the selection criteria for compulsory voting is not subject to manipulation. Even though it is highly improbable that the timing of births is affected by the date of the election, we follow the procedure from Frandsen (2013), which tests the bunching of the running variable in a similar way to McCrary (2008), but allowing for a discrete running variable. The results in Table A.1 show that we fail to reject the null hypothesis of no manipulation for both cutoffs. Furthermore, one can see in Figures A.4 and A.5 that the running variable is smooth around both

$2 \quad$ Although optimal bandwidth selection procedures are often used in the literature, we avoid doing so because of the nature of our running variable. All of these selection procedures assume that the conditional expectation is at least two times continuously differentiable, which implies the assumption that the running variable is continuously distributed, a condition we are not able to satisfy given our available data. For more information, see Calonico, Cattaneo \& Titiunik (2014). 
thresholds. The second assumption requires that baseline covariates do not change because of the abstention fine, i.e., there shouldn't be a treatment effect of compulsory voting on predetermined characteristics of the individuals. The results in Figures A.2 and A.3 show that there's no causal effect of the forcing variable on baseline characteristics and, thus, that the pre-determined variables smooth around the threshold. Having satisfied these assumptions, we have that:

$$
\beta_{18}=\lim _{A_{i} \rightarrow 18^{+}} E\left(Y_{i} \mid A_{i}\right)-\lim _{A_{i} \rightarrow 18^{-}} E\left(Y_{i} \mid A_{i}\right)
$$

and

$$
\beta_{70}=\lim _{A_{i} \rightarrow 70^{-}} E\left(Y_{i} \mid A_{i}\right)-\lim _{A_{i} \rightarrow 70^{+}} E\left(Y_{i} \mid A_{i}\right)
$$

This causal parameter of interest $\beta_{k}$ is the average impact of compulsory voting on a random individual at the cutoff. Under both the unconfoundedness and continuity assumption, we can say that any change in outcome $Y_{i}$ at the threshold is caused by the fact that the individual is subject to the changes that reaching the cutoff age entails. 



\section{Results}

We begin our analysis by focusing on citizens who were first exposed to the mandatory voting law in order to minimize issues that may arise due to the cumulative effect that compulsory voting may have on political engagement through habit formation (FUJIWARA; MENG; VOGL, 2013). Our largest bandwidth of choice consists of a 24 months open interval which includes citizens who were born between October 1994 and October 1998, i.e., those who where younger than 20 and older than 16 by the time of the federal elections of October 2014. This ensures that that every individual born between September 1994 and September 1996 is facing for the first time the abstention penalties, and that everyone with birth date between November, 1996 and September, 1998 has never been subject to the compulsory voting legislation. We run our main specification for five different bandwidths and two different functional forms, since we are interested in identifying significant effects that are robust to different combinations of these elements.

In order to find out what is the effect of the abstention penalties on the consumption of Rede Globo's Jornal Nacional we use the following question posed to individuals in the two waves of the Brazilian Media Survey:

- What is the TV show that you watch the most during the week?

This is an open-ended question which is repeated three times in order to find the respondents first, second and third favorite show in both cable and broadcast TV. We create an indicator variable coded to take value 1 whenever the respondent says that Rede Globo's Jornal Nacional is one of 
the three TV shows that she watches the most during the week and use it as our dependent variable of choice.

Our results can be found in Table A.4. We find a remarkably stable coefficient for the treatment effect, achieving significance in nine out of the ten different specifications we run. Since our dependent variable is a dummy (i.e. our regressions are linear probability models) the interpretation of the coefficients is straightforward. For the linear local regression in the intermediate bandwidth of sixteen months we find that a change from the voluntary voting to the mandatory voting regime increases the probability of an individual to name Jornal Nacional as one of her most watched shows in $10.4 \%$, a two-digit effect that can be attributed to the fact that the citizen has just become subject to abstention penalties. The same effect is illustrated in Figure A.8, where citizens past their 18th birthday in October, 2014 and for whom turnout is mandatory are plotted on the right side of 0 , while those who are 17 years and 11 months old or younger are plotted on the left side.

Although this substantial and statistically significant effect points to an impact of the abstention penalty on information acquisition, it tells us only half of the story. We must now turn our attention to the elderly voters at their 70th birthday, the second cutoff that determines exposure to compulsory voting. These are individuals who have been subject to the abstention penalties in every election since they were 18 years old and were about to switching voting regimes in the October 2014 elections. We run the same specifications as we did with young voters, but now focusing on those who were born between October 1942 and October 1946, i.e., using the 
same 24 months window as our largest bandwidth. The results can be found in Table A.5 and Figure A.9. No significant treatment effect is found and coefficients vary greatly across different functional forms.

These results show that the law has different effects when it comes to inducing the consumption of information. We have found that, at one hand, for those exposed to the abstention penalties for the first time and changing from a voluntary voting to a compulsory voting regime, it has a substantial and robust impact on the audience of Rede Globo's Jornal Nacional. On the other hand, for those who were subject to the penalties for decades and are transitioning from a mandatory to a voluntary voting regime, we cannot reject the null hypothesis that the law has no effect. 



\section{Robustness}

Even though all baseline covariates are balanced at both discontinuities and there's no reason to believe that any manipulation of the forcing variable took place in our sample, we must still address some possible confounding factors that may compromise our results.

First of all, it is possible that the impact we've found for young voters is not restricted to Jornal Nacional. Individuals may be watching other newscasts or might be just watching more TV. In order to check this we create three different indicators which we use as dependent variables. The first one takes value 1 whenever the respondent says that one of the newscasts broadcasted by the four major TV networks in Brazil, namely Globo, SBT, Band and Record, are one of the three TV shows that he or she watches the most. The second dependent variable takes value 1 whenever the respondent says that soccer games are one of the three three TV shows that she watches the most. Finally, the third dependent variable takes value 1 whenever the respondent says that the 7:30pm or the 9:00pm soap operas broadcasted by Rede Globo are one of the three TV shows that she watches the most. Since Jornal Nacional goes on air from 8:30pm until 9:00pm, it is possible that viewers are merely watching the newscast by inertia, when what they're truly seeking to consume is entertainment.

The results can be found In Tables A.6 and A.7 and Figures A.10 and A.11. Although some statistically significant coefficients are detected for the case of soap operas at the 70th birthday cutoff, only one of them is robust 
when we change the order of our local polynomial. ${ }^{1}$ These results support the idea that voters, when induced to attend the ballots and make a political decision, are using Jornal Nacional as their main source of information, and not just consuming different newscasts in order to diversify the news coverage they are exposed to or just watching more TV.

An additional issue that may affect our estimates is the possible effects caused by other programs that use age-based assignment mechanisms with cutoffs that coincide with ours. In Brazil, this is the case of military draft, the right to buy alcohol and the right to have a driver's license at the age of eighteen. Since our treatment assignment rule is defined by becoming a certain age at a specific month and year, not just becoming a certain age in any month, as is the case of these other programs, we shouldn't expect them to affect how voters acquire information.

Nevertheless, in order to test for these potential confounding factors, we first estimate the treatment effect of the exposure to abstention penalties for the illiterate population. These citizens are subject to the voluntary voting regime starting from the age of sixteen, but are never under the mandatory voting rule. This means they can always register to vote, but they are never under the threat of penalties in case they abstain from the elections. In this case, the assignment mechanisms at the ages of eighteen and seventy do not apply to them and we should not expect to detect any impact of the mandatory voting law on the consumption of Jornal Nacional. Additionally,

1 For more information on the robustness of results for RDD see Lee \& Lemieux (2010) and Gelman \& Imbens (2014) 
illiterate citizens are eligible to the military and have the right buy alcohol at the age of eighteen. If it was the case that such eligibility rules have impact on the consumption of information, we should be able to detect the effect on media consumption for this population also. As we can see in Table A.8, becoming eighteen or seventy has no effect for the illiterates when it comes to information acquisition through Jornal Nacional. As a last robustness check, we test for treatment effects at different placebo cutoffs for the election month. The results can be found in Tables A.9 and A.10. Even though few significant coefficients are found, no robust effect is present in the placebo cutoffs for the two age groups. 



\section{Concluding Remarks}

The interaction between the media and political institutions is a matter of great relevance to the current research agenda in political economy. Although a large literature about how the media affects outcomes such as turnout and civic engagement has been developed in the last decades, little attention has been paid to the opposite relation, i.e., how political institutions impact the way citizens consume and relate to the media.

In this dissertation we document the effects of compulsory voting on information consumption. Compulsory voting, by inducing political participation in elections, places citizens in a position where they must make the most important action one can in a democracy: the vote. According to the model we propose, citizens, in order to manifest their political preferences in a way that best represents their interests, must acquire information through the available channels provided by the media.

We find that, for citizens exposed for the first time to the abstention penalties, the law increases their probability to watch Jornal Nacional, Brazil's most trusted newscast, in $10.4 \%$ for our main specification. No robust impact is found for the consumption of other newscasts or non-journalistic TV shows on both discontinuities that determine the exposure to the penalties, and no impact is found at placebo cutoffs.

By employing an internally valid design to assess the effects of compulsory voting on information acquisition, we shed new light on the relation between political institutions and the media. Ultimately, this dissertation 
shows that, by increasing turnout, we are also nudging citizens into becoming more informed. 


\section{Referências}

ALT, J. E.; LASSEN, D. D.; MARSHALL, J. Information sources, belief updating, and the politics of economic expectations: Evidence from a Danish survey experiment. [S.1.], 2014. 14

BIRCH, S. Full participation: A comparative study of compulsory voting. [S.l.]: Manchester University Press, 2009. 14

CALONICO, S.; CATTANEO, M. D.; TITIUNIK, R. Robust nonparametric confidence intervals for regression-discontinuity designs. Econometrica, v. 82, n. 6 , p. 2295-2326, 2014. 32

CEPALUNI, G.; HIDALGO, F. D. Compulsory voting can increase political inequality: Evidence from brazil. 2015. 25

CHIANG, C.-F.; KNIGHT, B. Media bias and influence: Evidence from newspaper endorsements. The Review of Economic Studies, p. 1-26, 2011. 14

DEGAN, A. Policy positions, information acquisition and turnout. The Scandinavian Journal of Economics, v. 108, n. 4, p. 669-682, 2006. 17, 22

DELLAVIGNA, S.; KAPLAN, E. D. The fox news effect: Media bias and voting. The Quarterly Journal of Economics, MIT Press, v. 122, n. 3, p. 1187-1234, 2007. 15

FERRARA, E. L.; CHONG, A.; DURYEA, S. Soap operas and fertility: Evidence from brazil. American Economic Journal: Applied Economics, p. $1-31,2012.26$

FRANDSEN, B. R. Party bias in union representation elections: Testing for manipulation in the regression discontinuity design when the running variable is discrete. Mimeo, Brigham Young University, 2013. 32, 58

FUJIWARA, T.; MENG, K. C.; VOGL, T. Estimating habit formation in voting. [S.1.], 2013. 35

GELMAN, A.; IMBENS, G. Why high-order polynomials should not be used in regression discontinuity designs. [S.1.], 2014. 32, 40

GENTZKOW, M. Television and voter turnout. The Quarterly Journal of Economics, p. 931-972, 2006. 15 
GORDON, S. B.; SEGURA, G. M. Cross-national variation in the political sophistication of individuals: Capability or choice? The Journal of Politics, Cambridge Univ Press, v. 59, n. 01, p. 126-147, 1997. 14

GROSSER, J.; SEEBAUER, M. et al. The curse of uninformed voting: An experimental study. [S.1.], 2008. 14

LEE, D. S.; CARD, D. Regression discontinuity inference with specification error. Journal of Econometrics, v. 142, n. 2, p. 655-674, 2008. 32

LEE, D. S.; LEMIEUX, T. Regression discontinuity designs in economics. Journal of Economic Literature, v. 48, p. 281-355, 2010. 31, 40

LEON, F. L. L. de; RIZZI, R. A test for the rational ignorance hypothesis: Evidence from a natural experiment in brazil. American Economic Journal: Economic Policy, v. 6, n. 4, p. 380-398, 2014. 15, 26, 30

LEÓN, G. Turnout, political preferences and information: Experimental evidence from perú. 2015. 17

LIJPHART, A. Unequal participation: Democracy's unresolved dilemma presidential address, american political science association, 1996. American political science review, Cambridge Univ Press, v. 91, n. 01, p. 1-14, 1997. 13

LOEWEN, P. J.; MILNER, H.; HICKS, B. M. Does compulsory voting lead to more informed and engaged citizens? an experimental test. Canadian Journal of Political Science, Cambridge Univ Press, v. 41, n. 03, p. 655-672, 2008. 14

MCCRARY, J. Manipulation of the running variable in the regression discontinuity design: A density test. Journal of Econometrics, v. 142, n. 2, p. 698-714, 2008. 32

MESQUITA, N. Jornal nacional, democracia e confiança nas instituições democráticas. Democracia e Confiança: por que os cidadãos desconfiam das instituições públicas, p. 185-216, 2010. 27

PORTO, M. Tv news and political change in brazil the impact of democratization on tv globo's journalism. Journalism, SAGE Publications, v. 8 , n. 4 , p. 363-384, 2007. 14, 27

[Bibliography] 
Apêndice A 


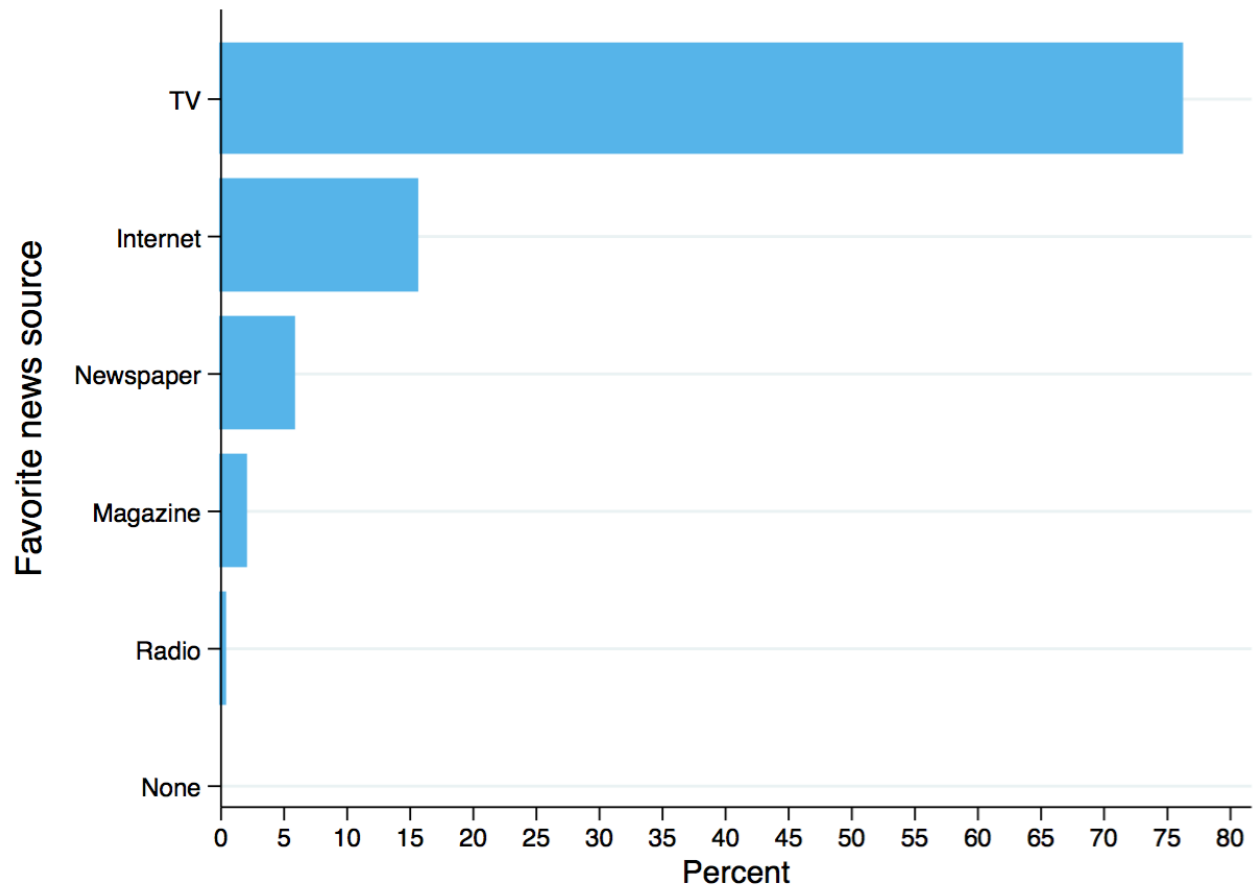

Figure A.1 - Favorite source of information. 


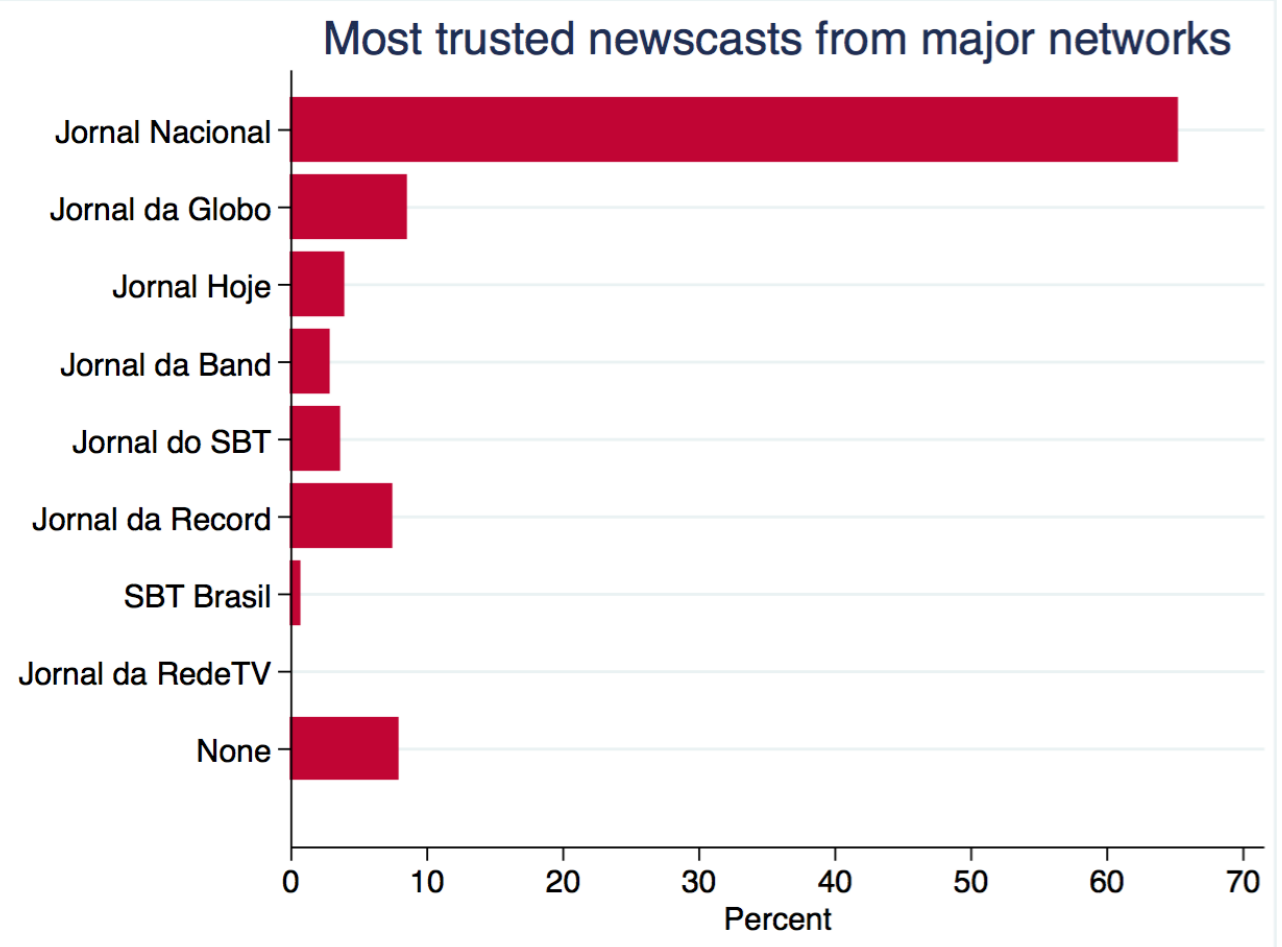

Figure A.2 - Most trusted newscast.

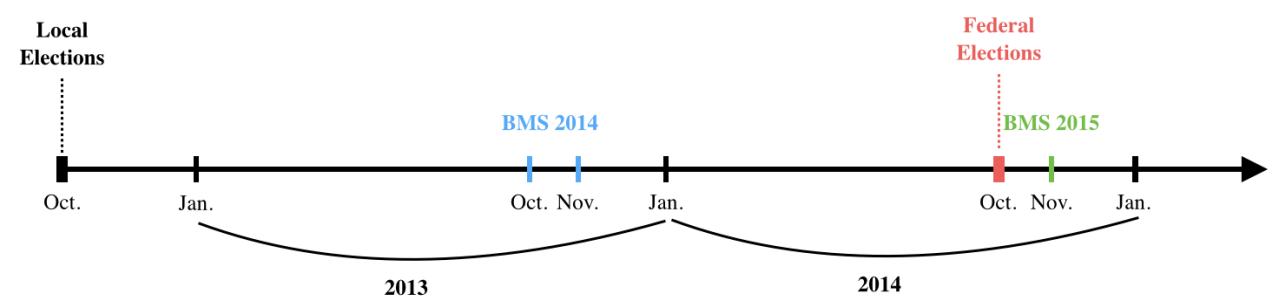

Figure A.3 - Brazilian Media Survey timing. 


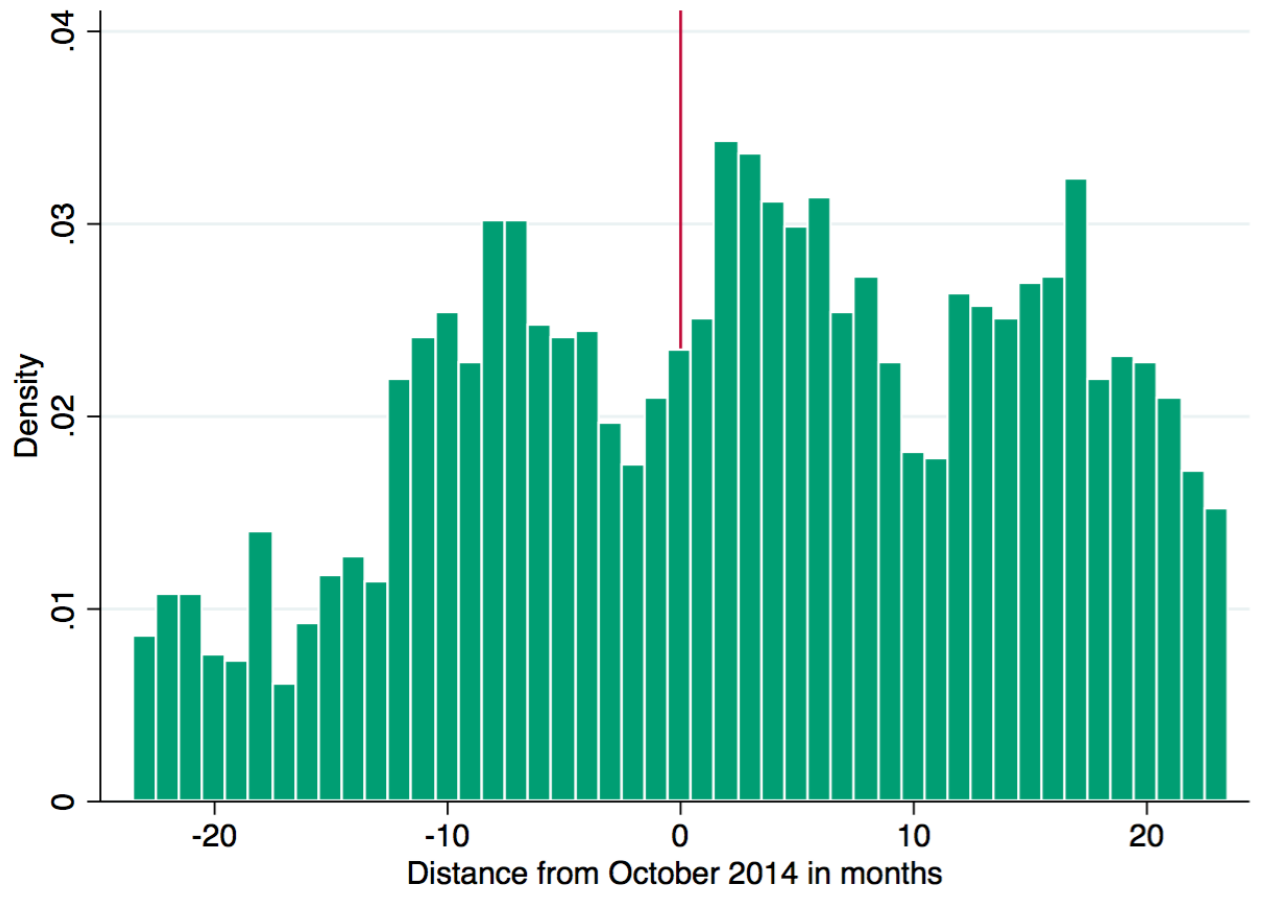

Figure A.4 - Histogram of the centered age of individuals in months for cutoff at the 18th birthday. 


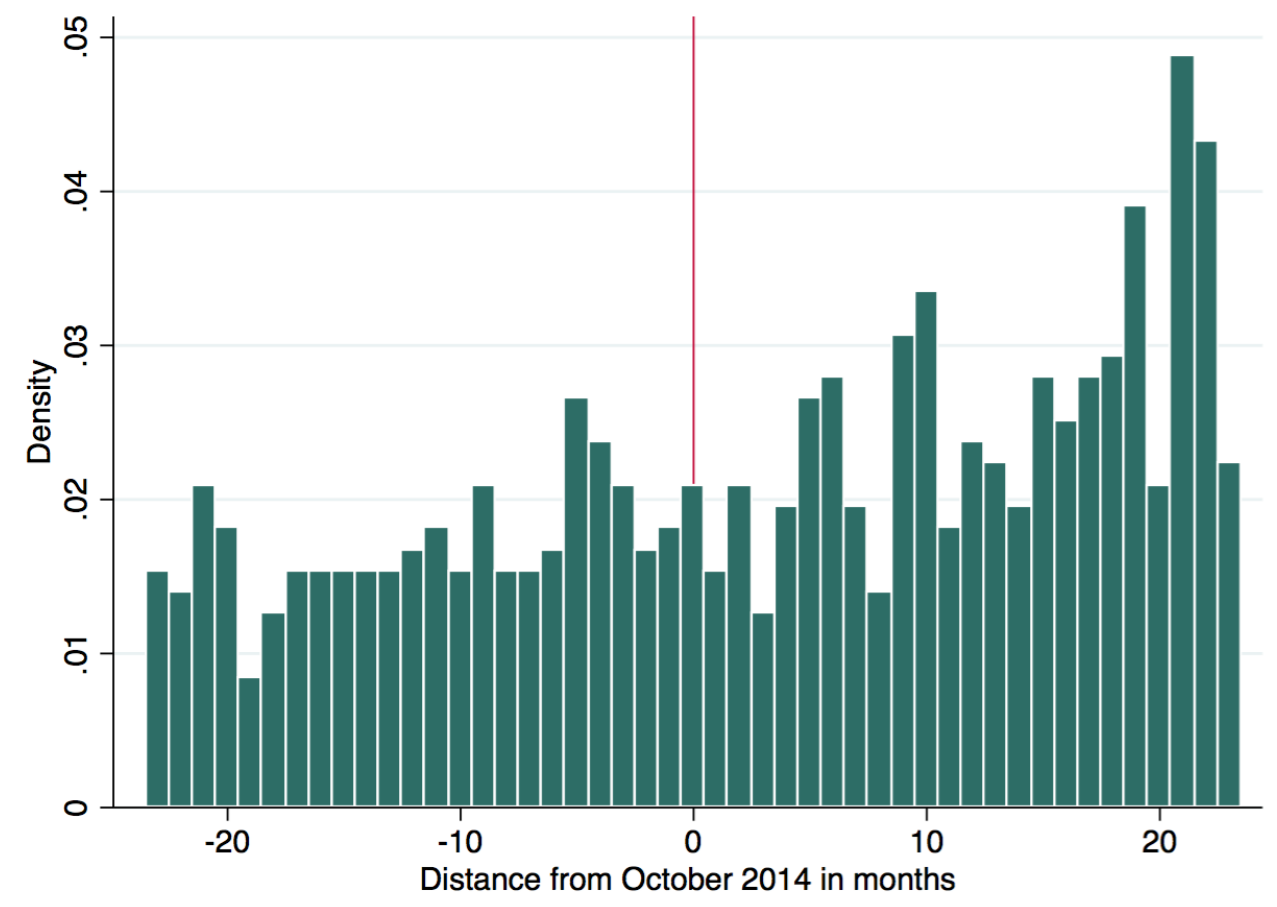

Figure A.5 - Histogram of the centered age of individuals in months for cutoff at the 70th birthday. 

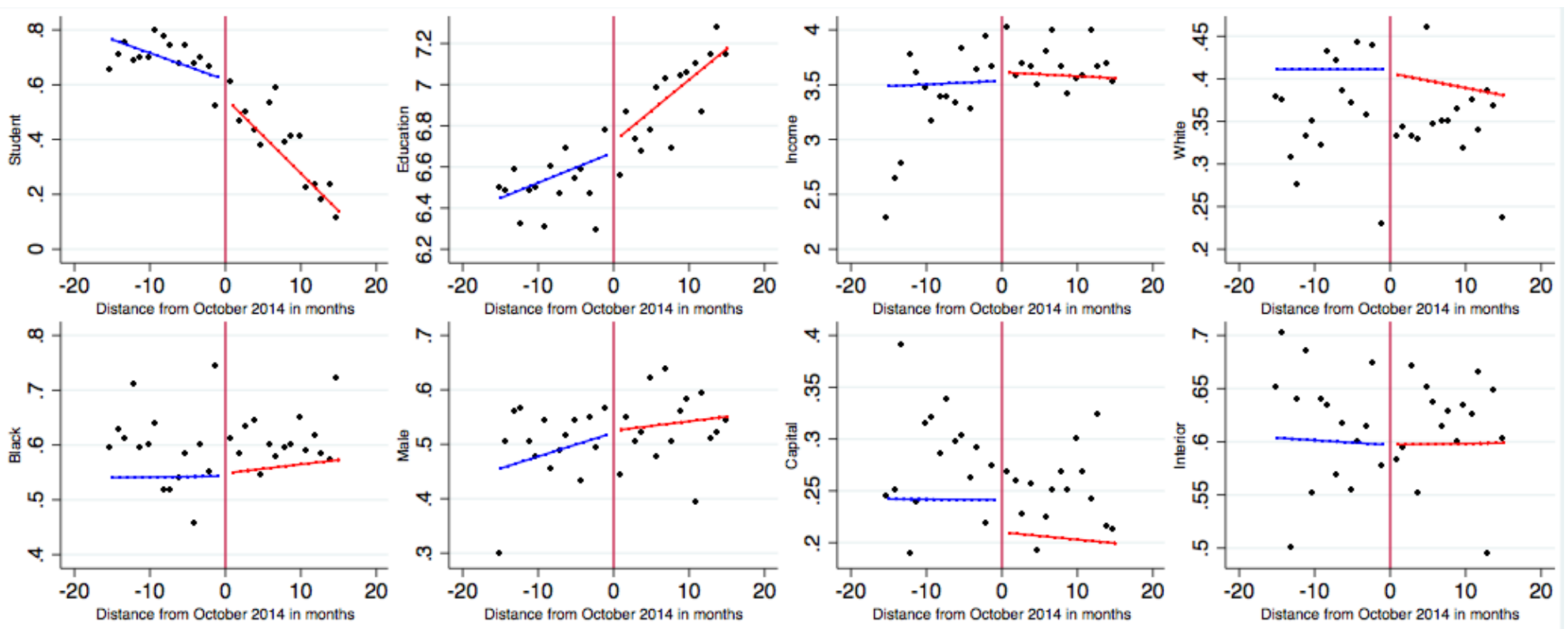

Figure A.6 - Covariate balance around the 18th birthday cutoff. 

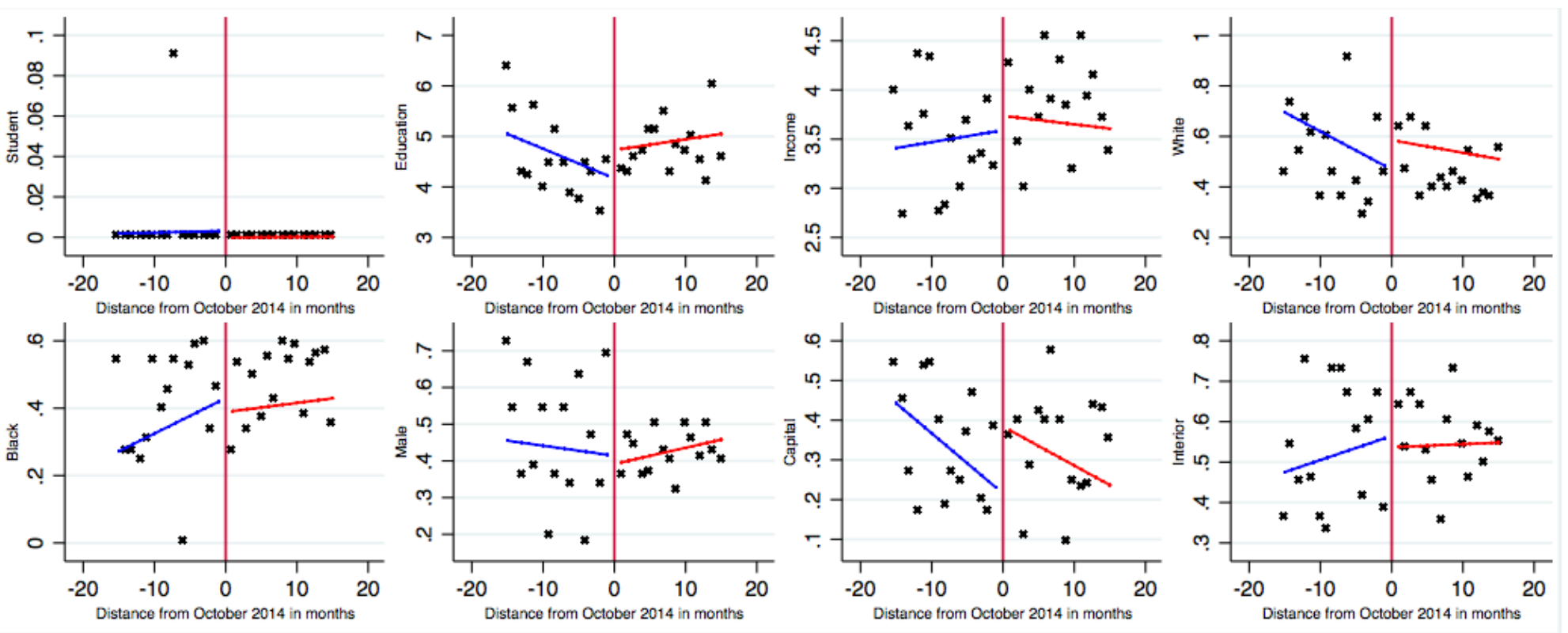

Figure A.7 - Covariate balance around the 70th birthday cutoff. 


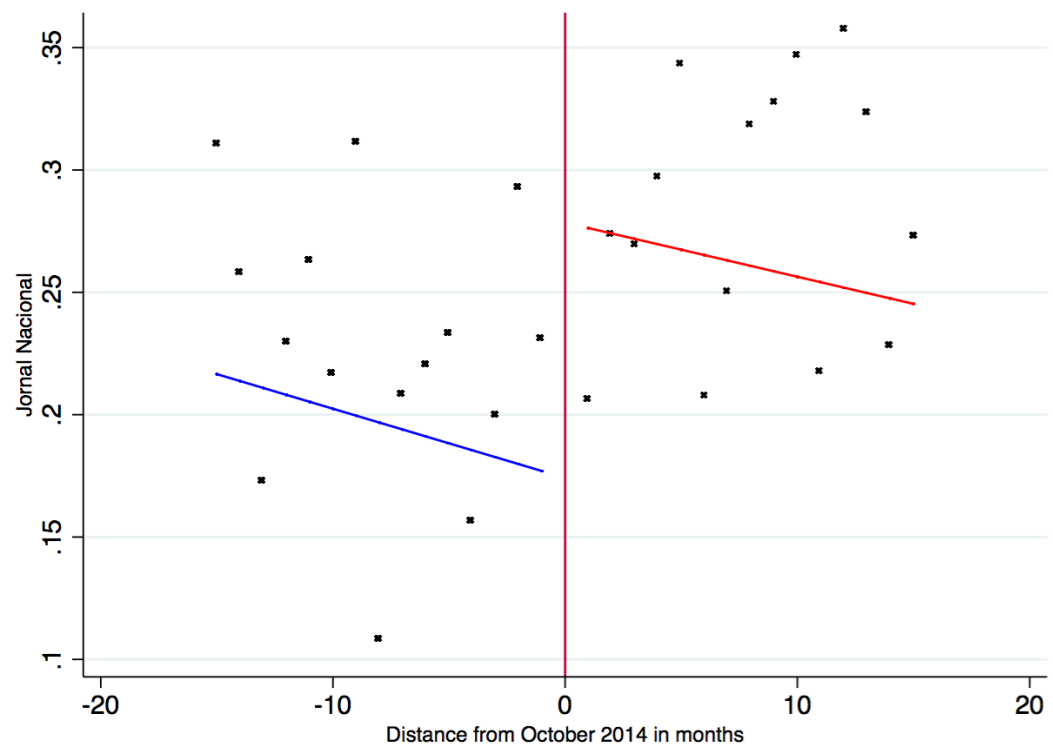

Figure A.8 - Treatment effect of exposure to abstention penalties on the consumption of Jornal Nacional at the 18th birthday cutoff. 


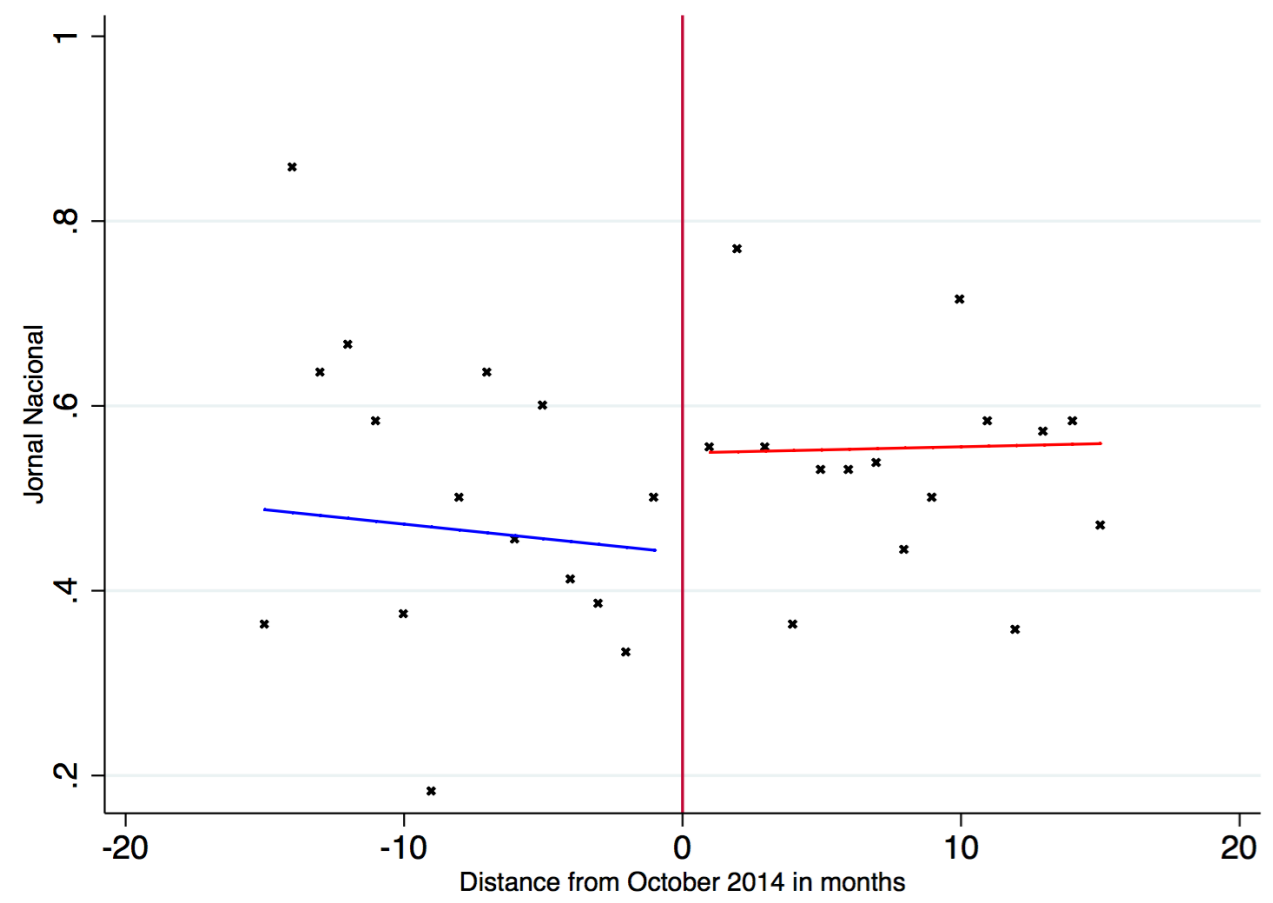

Figure A.9 - Treatment effect of exposure to abstention penalties on the consumption of Jornal Nacional at the 70th birthday cutoff. 

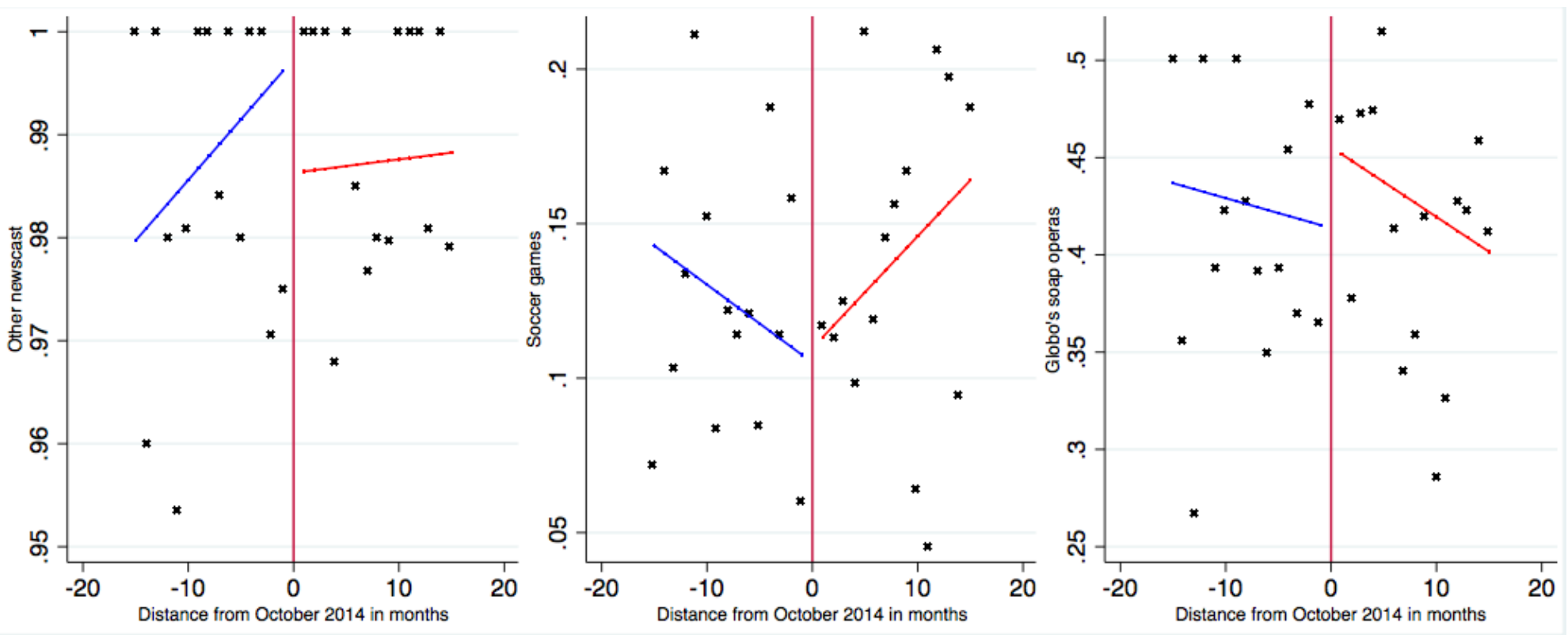

Figure A.10 - Treatment effect of exposure to abstention penalties on the consumption of other TV shows at the 18th birthday cutoff. 

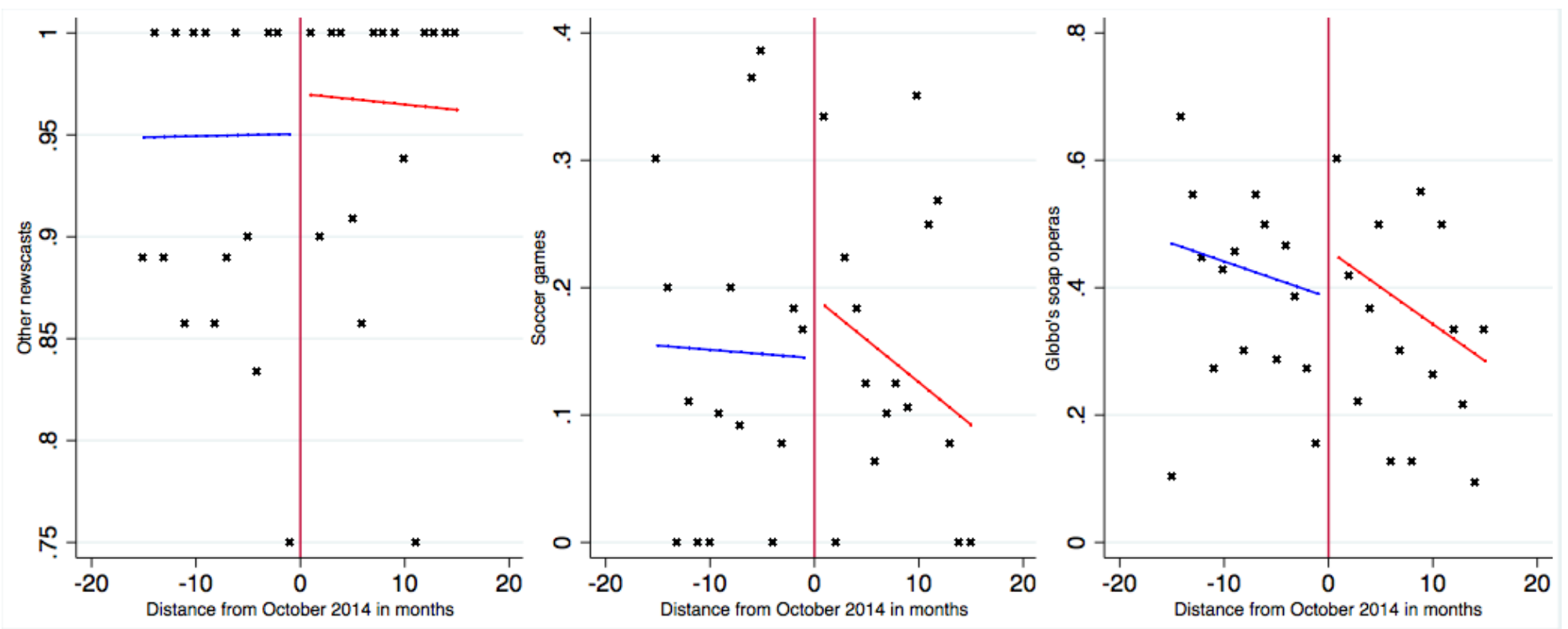

Figure A.11 - Treatment effect of exposure to abstention penalties on the consumption of other TV shows at the 70th birthday cutoff. 
Table A.1 - RDD density test for discrete running variable.

\begin{tabular}{cc}
\hline Cutoffs & p-value \\
\hline \hline 18th birthday & 0.824 \\
70 th birthday & 0.393
\end{tabular}

Notes: The null hypothesis is that there is no manipulation around the cutoffs. Density tests done following Frandsen (2013). Sample consists of literate citizens who responded the Brazilian Media Survey at the years of 2013 and 2014. 
Table A.2 - Covariate balance around the 18th birthday cutoff.

\begin{tabular}{|c|c|c|c|c|c|}
\hline Dependent variables & (1) & (2) & (3) & (4) & (5) \\
\hline \multicolumn{6}{|c|}{ Panel A: First order polynomial } \\
\hline Student & $\begin{array}{l}-0.104 \\
(0.072)\end{array}$ & $\begin{array}{c}-0.123 \\
(0.050)^{* *}\end{array}$ & $\begin{array}{l}-0.068 \\
(0.048)\end{array}$ & $\begin{array}{c}-0.139 \\
(0.053)^{* *}\end{array}$ & $\begin{array}{c}-0.143 \\
(0.046) * * *\end{array}$ \\
\hline Education & $\begin{array}{l}-0.068 \\
(0.179)\end{array}$ & $\begin{array}{l}-0.003 \\
(0.123)\end{array}$ & $\begin{array}{c}0.051 \\
(0.102)\end{array}$ & $\begin{array}{l}-0.006 \\
(0.094)\end{array}$ & $\begin{array}{c}-0.013 \\
(0.084)\end{array}$ \\
\hline Income & $\begin{array}{l}-0.002 \\
(0.086)\end{array}$ & $\begin{array}{c}0.020 \\
(0.109)\end{array}$ & $\begin{array}{c}0.077 \\
(0.102)\end{array}$ & $\begin{array}{c}0.068 \\
(0.087)\end{array}$ & $\begin{array}{c}0.081 \\
(0.078)\end{array}$ \\
\hline Male & $\begin{array}{l}-0.052 \\
(0.070)\end{array}$ & $\begin{array}{l}-0.008 \\
(0.057)\end{array}$ & $\begin{array}{c}0.004 \\
(0.050)\end{array}$ & $\begin{array}{c}0.069 \\
(0.047)\end{array}$ & $\begin{array}{c}0.078 \\
(0.042)^{*}\end{array}$ \\
\hline White & $\begin{array}{c}0.027 \\
(0.065)\end{array}$ & $\begin{array}{c}0.002 \\
(0.060)\end{array}$ & $\begin{array}{l}-0.004 \\
(0.056)\end{array}$ & $\begin{array}{l}-0.020 \\
(0.051)\end{array}$ & $\begin{array}{l}-0.011 \\
(0.044)\end{array}$ \\
\hline Black & $\begin{array}{l}-0.037 \\
(0.072)\end{array}$ & $\begin{array}{l}-0.009 \\
(0.066)\end{array}$ & $\begin{array}{c}0.005 \\
(0.063)\end{array}$ & $\begin{array}{c}0.024 \\
(0.056)\end{array}$ & $\begin{array}{c}0.018 \\
(0.047)\end{array}$ \\
\hline Capital & $\begin{array}{l}-0.008 \\
(0.055)\end{array}$ & $\begin{array}{l}-0.041 \\
(0.045)\end{array}$ & $\begin{array}{l}-0.031 \\
(0.037)\end{array}$ & $\begin{array}{c}-0.056 \\
(0.032)^{*}\end{array}$ & $\begin{array}{c}-0.071 \\
(0.030)^{* *}\end{array}$ \\
\hline Countryside & $\begin{array}{l}-0.023 \\
(0.083)\end{array}$ & $\begin{array}{c}0.004 \\
(0.062)\end{array}$ & $\begin{array}{c}0.000 \\
(0.051)\end{array}$ & $\begin{array}{l}-0.006 \\
(0.044)\end{array}$ & $\begin{array}{c}0.013 \\
(0.039)\end{array}$ \\
\hline \multicolumn{6}{|c|}{ Panel B: Second order polynomial } \\
\hline Student & $\begin{array}{c}0.162 \\
(0.048)^{* * *}\end{array}$ & $\begin{array}{l}-0.051 \\
(0.099)\end{array}$ & $\begin{array}{l}-0.122 \\
(0.072)\end{array}$ & $\begin{array}{c}-0.012 \\
(0.058)\end{array}$ & $\begin{array}{l}-0.055 \\
(0.054)\end{array}$ \\
\hline Education & $\begin{array}{c}0.191 \\
(0.224)\end{array}$ & $\begin{array}{l}-0.030 \\
(0.223)\end{array}$ & $\begin{array}{l}-0.027 \\
(0.192)\end{array}$ & $\begin{array}{c}0.056 \\
(0.166)\end{array}$ & $\begin{array}{c}0.064 \\
(0.136)\end{array}$ \\
\hline Income & $\begin{array}{c}0.139 \\
(0.193)\end{array}$ & $\begin{array}{l}-0.093 \\
(0.131)\end{array}$ & $\begin{array}{l}-0.094 \\
(0.118)\end{array}$ & $\begin{array}{l}-0.050 \\
(0.114)\end{array}$ & $\begin{array}{l}-0.026 \\
(0.111)\end{array}$ \\
\hline Male & $\begin{array}{l}-0.061 \\
(0.115)\end{array}$ & $\begin{array}{l}-0.088 \\
(0.081)\end{array}$ & $\begin{array}{l}-0.037 \\
(0.075)\end{array}$ & $\begin{array}{l}-0.075 \\
(0.060)\end{array}$ & $\begin{array}{l}-0.030 \\
(0.059)\end{array}$ \\
\hline White & $\begin{array}{c}0.017 \\
(0.102)\end{array}$ & $\begin{array}{c}0.086 \\
(0.083)\end{array}$ & $\begin{array}{c}0.028 \\
(0.079)\end{array}$ & $\begin{array}{c}0.013 \\
(0.076)\end{array}$ & $\begin{array}{l}-0.012 \\
(0.070)\end{array}$ \\
\hline Black & $\begin{array}{l}-0.143 \\
(0.100)\end{array}$ & $\begin{array}{l}-0.118 \\
(0.087)\end{array}$ & $\begin{array}{l}-0.051 \\
(0.084)\end{array}$ & $\begin{array}{l}-0.023 \\
(0.084)\end{array}$ & $\begin{array}{c}0.001 \\
(0.081)\end{array}$ \\
\hline Capital & $\begin{array}{l}-0.037 \\
(0.092)\end{array}$ & $\begin{array}{c}0.025 \\
(0.076)\end{array}$ & $\begin{array}{l}-0.031 \\
(0.057)\end{array}$ & $\begin{array}{l}-0.013 \\
(0.052)\end{array}$ & $\begin{array}{l}-0.016 \\
(0.047)\end{array}$ \\
\hline Countryside & $\begin{array}{c}0.079 \\
(0.127)\end{array}$ & $\begin{array}{l}-0.032 \\
(0.112)\end{array}$ & $\begin{array}{l}-0.018 \\
(0.087)\end{array}$ & $\begin{array}{l}0.008 \\
(0.077)\end{array}$ & $\begin{array}{l}-0.018 \\
(0.067)\end{array}$ \\
\hline Bandwidth & $\pm 8 \mathrm{mos}$ & \pm 12 mos. & $\pm 16 \mathrm{mos}$ & \pm 20 mos. & $\pm 24 \mathrm{mos}$ \\
\hline
\end{tabular}

Notes: Each figure in the table is from a separate local regression with the specified bandwidth and polynomial. Household income is measured on a scale from one to six, where one stands for one minimum wage and six stands for over 20 minimum wages. Education is measured on a scale from 1 to 10 , where 1 stands for being illiterate and 10 stands for having successfully obtained a college degree. Since the compulsory voting law does not apply to illiterate citizens, all values are calculated only for the literate population. All other variables are indicators for demographic characteristics. Sample consists of literate citizens who responded the Brazilian Media Survey at the years of 2013 and 2014. All standard errors are clustered on age measured in months and all regressions include survey year fixed-effects. Significance: ${ }^{* * *} \mathrm{p}<0.01,{ }^{* *} \mathrm{p}<0.05,{ }^{*} \mathrm{p}<0.1$. 
Table A.3 - Covariate balance around the 70th birthday cutoff.

\begin{tabular}{|c|c|c|c|c|c|}
\hline Dependent variables & $(1)$ & $(2)$ & (3) & $(4)$ & $(5)$ \\
\hline \multicolumn{6}{|c|}{ Panel A: First order polynomial } \\
\hline Student & $\begin{array}{c}0.013 \\
(0.010)\end{array}$ & $\begin{array}{l}-0.001 \\
(0.002)\end{array}$ & $\begin{array}{l}-0.003 \\
(0.004)\end{array}$ & $\begin{array}{l}-0.004 \\
(0.004)\end{array}$ & $\begin{array}{l}-0.004 \\
(0.004)\end{array}$ \\
\hline Education & $\begin{array}{l}-0.610 \\
(0.792)\end{array}$ & $\begin{array}{c}0.638 \\
(0.653)\end{array}$ & $\begin{array}{c}0.559 \\
(0.497)\end{array}$ & $\begin{array}{c}0.370 \\
(0.445)\end{array}$ & $\begin{array}{c}0.424 \\
(0.418)\end{array}$ \\
\hline Income & $\begin{array}{c}0.162 \\
(0.437)\end{array}$ & $\begin{array}{c}0.164 \\
(0.311)\end{array}$ & $\begin{array}{c}0.147 \\
(0.253)\end{array}$ & $\begin{array}{c}0.230 \\
(0.201)\end{array}$ & $\begin{array}{c}0.151 \\
(0.181)\end{array}$ \\
\hline Male & $\begin{array}{l}-0.127 \\
(0.194)\end{array}$ & $\begin{array}{l}-0.116 \\
(0.145)\end{array}$ & $\begin{array}{l}-0.022 \\
(0.126)\end{array}$ & $\begin{array}{l}0.000 \\
(0.108)\end{array}$ & $\begin{array}{l}-0.009 \\
(0.100)\end{array}$ \\
\hline White & $\begin{array}{c}0.094 \\
(0.172)\end{array}$ & $\begin{array}{c}0.112 \\
(0.123)\end{array}$ & $\begin{array}{c}0.116 \\
(0.113)\end{array}$ & $\begin{array}{c}0.069 \\
(0.102)\end{array}$ & $\begin{array}{c}0.088 \\
(0.095)\end{array}$ \\
\hline Black & $\begin{array}{l}-0.116 \\
(0.174)\end{array}$ & $\begin{array}{l}-0.097 \\
(0.122)\end{array}$ & $\begin{array}{l}-0.041 \\
(0.117)\end{array}$ & $\begin{array}{l}-0.005 \\
(0.097)\end{array}$ & $\begin{array}{l}-0.024 \\
(0.091)\end{array}$ \\
\hline Capital & $\begin{array}{c}0.166 \\
(0.146)\end{array}$ & $\begin{array}{c}0.321 \\
(0.111)^{* * *}\end{array}$ & $\begin{array}{c}0.169 \\
(0.099) *\end{array}$ & $\begin{array}{c}0.041 \\
(0.102)\end{array}$ & $\begin{array}{c}0.022 \\
(0.096)\end{array}$ \\
\hline Countryside & $\begin{array}{c}0.129 \\
(0.127)\end{array}$ & $\begin{array}{l}-0.085 \\
(0.102)\end{array}$ & $\begin{array}{c}-0.028 \\
(0.089)\end{array}$ & $\begin{array}{c}0.001 \\
(0.092)\end{array}$ & $\begin{array}{c}0.005 \\
(0.085)\end{array}$ \\
\hline \multicolumn{6}{|c|}{ Panel B: Second order polynomial } \\
\hline Student & $\begin{array}{c}-0.021 \\
(0.011)^{*}\end{array}$ & $\begin{array}{c}0.009 \\
(0.009)\end{array}$ & $\begin{array}{c}0.004 \\
(0.004)\end{array}$ & $\begin{array}{c}0.001 \\
(0.002)\end{array}$ & $\begin{array}{l}-0.002 \\
(0.002)\end{array}$ \\
\hline Education & $\begin{array}{l}-1.552 \\
(1.072)\end{array}$ & $\begin{array}{l}-0.847 \\
(1.005)\end{array}$ & $\begin{array}{c}0.034 \\
(0.908)\end{array}$ & $\begin{array}{c}0.553 \\
(0.831)\end{array}$ & $\begin{array}{c}0.362 \\
(0.673)\end{array}$ \\
\hline Income & $\begin{array}{c}1.312 \\
(0.496)^{* *}\end{array}$ & $\begin{array}{c}0.080 \\
(0.612)\end{array}$ & $\begin{array}{c}0.107 \\
(0.498)\end{array}$ & $\begin{array}{c}0.002 \\
(0.398)\end{array}$ & $\begin{array}{c}0.193 \\
(0.322)\end{array}$ \\
\hline Male & $\begin{array}{c}-0.665 \\
(0.232)^{* *}\end{array}$ & $\begin{array}{l}-0.263 \\
(0.217)\end{array}$ & $\begin{array}{l}-0.251 \\
(0.179)\end{array}$ & $\begin{array}{l}-0.160 \\
(0.167)\end{array}$ & $\begin{array}{l}-0.054 \\
(0.163)\end{array}$ \\
\hline White & $\begin{array}{l}-0.036 \\
(0.268)\end{array}$ & $\begin{array}{c}0.129 \\
(0.188)\end{array}$ & $\begin{array}{c}0.156 \\
(0.151)\end{array}$ & $\begin{array}{c}0.198 \\
(0.143)\end{array}$ & $\begin{array}{c}0.099 \\
(0.135)\end{array}$ \\
\hline Black & $\begin{array}{l}-0.056 \\
(0.246)\end{array}$ & $\begin{array}{l}-0.169 \\
(0.192)\end{array}$ & $\begin{array}{l}-0.222 \\
(0.153)\end{array}$ & $\begin{array}{l}-0.193 \\
(0.144)\end{array}$ & $\begin{array}{l}-0.075 \\
(0.136)\end{array}$ \\
\hline Capital & $\begin{array}{c}0.549 \\
(0.198)^{* *}\end{array}$ & $\begin{array}{c}0.173 \\
(0.167)\end{array}$ & $\begin{array}{c}0.346 \\
(0.146)^{* *}\end{array}$ & $\begin{array}{c}0.347 \\
(0.129)^{* *}\end{array}$ & $\begin{array}{c}0.243 \\
(0.116)^{* *}\end{array}$ \\
\hline Countryside & $\begin{array}{l}-0.170 \\
(0.208)\end{array}$ & $\begin{array}{c}0.032 \\
(0.158)\end{array}$ & $\begin{array}{c}-0.046 \\
(0.154)\end{array}$ & $\begin{array}{l}-0.050 \\
(0.130)\end{array}$ & $\begin{array}{l}-0.037 \\
(0.112)\end{array}$ \\
\hline Bandwidth & \pm 8 mos. & \pm 12 mos. & \pm 16 mos. & \pm 20 mos. & \pm 24 mos. \\
\hline
\end{tabular}

Notes: Each figure in the table is from a separate local regression with the specified bandwidth and polynomial. Household income is measured on a scale from one to six, where one stands for one minimum wage and six stands for over 20 minimum wages. Education is measured on a scale from 1 to 10 , where 1 stands for being illiterate and 10 stands for having successfully obtained a college degree. Since the compulsory voting law does not apply to illiterate citizens, all values are calculated only for the literate population. All other variables are indicators for demographic characteristics. Sample consists of literate citizens who responded the Brazilian Media Survey at the years of 2013 and 2014. All standard errors are clustered on age measured in months and all regressions include survey year fixed-effects. Significance: ${ }^{* * *} \mathrm{p}<0.01,{ }^{* *} \mathrm{p}<0.05,{ }^{*} \mathrm{p}<0.1$. 
Table A.4 - Treatment effect of exposure to abstention penalties on the consumption of Jornal Nacional at the 18th birthday cutoff.

\begin{tabular}{cccccc}
\hline Polynomial order & $(1)$ & $(2)$ & $(3)$ & $(4)$ & $(5)$ \\
\hline \hline \multirow{2}{*}{ First } & 0.092 & 0.115 & 0.104 & 0.093 & 0.088 \\
& $(0.024)^{* * *}$ & $(0.031)^{* * *}$ & $(0.027)^{* * *}$ & $(0.030)^{* * *}$ & $(0.028)^{* * *}$ \\
Second & 0.112 & 0.032 & 0.072 & 0.108 & 0.101 \\
& $(0.052)^{* *}$ & $(0.046)$ & $(0.034)^{* *}$ & $(0.036)^{* * *}$ & $(0.033)^{* * *}$ \\
Observations & 903 & 1,377 & 1,788 & 2,155 & 2,444 \\
Bandwidth & \pm 8 mos. & \pm 12 mos. & \pm 16 mos. & \pm 20 mos. & \pm 24 mos. \\
& & & & & \\
\hline
\end{tabular}

Notes: Each figure in the table is from a separate local regression with the specified bandwidth and polynomial. The dependent variable is an indicator which takes value 1 whenever the respondent says that Jornal Nacional is one of the three TV shows that he or she watches the most during the week. Sample consists of literate citizens who responded the Brazilian Media Survey at the years of 2013 and 2014. All standard errors are clustered on age measured in months and all regressions include survey year fixed-effects. Significance: ${ }^{* * *} \mathrm{p}<0.01,{ }^{* *} \mathrm{p}<0.05,{ }^{*} \mathrm{p}<0.1$.

Table A.5 - Treatment effect of exposure to abstention penalties on the consumption of Jornal Nacional at the 70th birthday cutoff.

\begin{tabular}{cccccc}
\hline Polynomial order & $(1)$ & $(2)$ & $(3)$ & $(4)$ & $(5)$ \\
\hline \hline \multirow{2}{*}{ First } & 0.183 & 0.080 & 0.108 & 0.065 & 0.053 \\
& $(0.161)$ & $(0.129)$ & $(0.112)$ & $(0.094)$ & $(0.086)$ \\
Second & 0.076 & 0.160 & 0.140 & 0.187 & 0.159 \\
& $(0.277)$ & $(0.209)$ & $(0.180)$ & $(0.150)$ & $(0.135)$ \\
Observations & 180 & 283 & 378 & 482 & 603 \\
Bandwidth & \pm 8 mos. & \pm 12 mos. & \pm 16 mos. & \pm 20 mos. & \pm 24 mos.
\end{tabular}

Notes: Each figure in the table is from a separate local regression with the specified bandwidth and polynomial. The dependent variable is an indicator which takes value 1 whenever the respondent says that Jornal Nacional is one of the three TV shows that he or she watches the most during the week. Sample consists of literate citizens who responded the Brazilian Media Survey at the years of 2013 and 2014. All standard errors are clustered on age measured in months and all regressions include survey year fixed-effects. Significance: $* * *$ $\mathrm{p}<0.01,{ }^{* *} \mathrm{p}<0.05,{ }^{*} \mathrm{p}<0.1$. 
Table A.6 - Treatment effect of exposure to abstention penalties on the consumption of other TV shows at the 18th birthday cutoff.

Polynomial order

Panel A: Other newscasts

First

Second

Panel B: Soccer games

First

Second

$$
(0.051)
$$

0.141

$(0.057)^{* *}$
(2)

(3)

(4)

(5)

Panel C: Soap operas

\begin{tabular}{cccccc} 
First & 0.086 & 0.108 & 0.042 & 0.049 & 0.031 \\
Second & $(0.072)$ & $(0.051)^{* *}$ & $(0.044)$ & $(0.037)$ & $(0.036)$ \\
& 0.029 & 0.080 & 0.150 & 0.079 & 0.081 \\
Bandwidth & $(0.132)$ & $(0.090)$ & $(0.074)^{*}$ & $(0.064)$ & $(0.059)$ \\
& \pm 8 mos. & \pm 12 mos. & \pm 16 mos. & \pm 20 mos. & \pm 24 mos. \\
\hline
\end{tabular}

Notes: Each figure in the table is from a separate local regression with the specified bandwidth and polynomial. Each panel displays the results for different dependent variables. Panel A presents the results for the dependent variable as an indicator which takes value 1 whenever the respondent says that SBT Brasil, Jornal da Record, Jornal da Band, Jornal Hoje, Jornal da Globo, Jornal da Noite or Jornal do SBT are one of the three TV shows that he or she watches the most. Panel B presents the results for the dependent variable as an indicator which takes value 1 whenever the respondent says that soccer games broadcasted by Globo, Band or Record are one of the three TV shows that he or she watches the most. Panel $\mathrm{C}$ presents the results for the dependent variable as an indicator which takes value 1 whenever the respondent says that the 7:30 pm or the 9:00 pm soap operas broadcasted by Rede Globo are one of the three TV shows that he or she watches the most. Sample consists of illiterate citizens who responded the Brazilian Media Survey at the years of 2013 and 2014. All standard errors are clustered on age measured in months and all regressions include survey year fixed-effects. Significance: $* * * \mathrm{p}<0.01, * * \mathrm{p}<0.05, * \mathrm{p}<0.1$. 
Table A.7 - Treatment effect of exposure to abstention penalties on the consumption of other TV shows at the 70th birthday cutoff.

Polynomial order

Panel A: Other newscasts

First

Second

Panel B: Soccer games

First

Second

(0.149)

0.210

(0.239)
(1)
(3)
(4)

(5)

Panel C: Soap operas

$\begin{array}{cccccc}\text { First } & 0.346 & 0.049 & 0.074 & 0.051 & -0.080 \\ \text { Second } & (0.103)^{* * *} & (0.144) & (0.126) & (0.103) & (0.105) \\ & 0.582 & 0.581 & 0.296 & 0.194 & 0.267 \\ \text { Bandwidth } & (0.145)^{* * *} & (0.100)^{* * *} & (0.162)^{*} & (0.145) & (0.128)^{* *} \\ & \pm 8 \text { mos. } & \pm 12 \text { mos. } & \pm 16 \text { mos. } & \pm 20 \text { mos. } & \pm 24 \text { mos. }\end{array}$

Notes: Each figure in the table is from a separate local regression with the specified bandwidth and polynomial. Each panel displays the results for different dependent variables. Panel A presents the results for the dependent variable as an indicator which takes value 1 whenever the respondent says that SBT Brasil, Jornal da Record, Jornal da Band, Jornal Hoje, Jornal da Globo, Jornal da Noite or Jornal do SBT are one of the three TV shows that he or she watches the most. Panel B presents the results for the dependent variable as an indicator which takes value 1 whenever the respondent says that soccer games broadcasted by Globo, Band or Record are one of the three TV shows that he or she watches the most. Panel $\mathrm{C}$ presents the results for the dependent variable as an indicator which takes value 1 whenever the respondent says that the 7:30 pm or the 9:00 pm soap operas broadcasted by Rede Globo are one of the three TV shows that he or she watches the most. Sample consists of illiterate citizens who responded the Brazilian Media Survey at the years of 2013 and 2014. All standard errors are clustered on age measured in months and all regressions include survey year fixed-effects. Significance: $*^{* *} \mathrm{p}<0.01,{ }^{* *} \mathrm{p}<0.05$, * $\mathrm{p}<0.1$. 
Table A.8 - Treatment effect of exposure to abstention penalties on the consumption of Jornal Nacional for illiterates.

\begin{tabular}{cccccc}
\hline Polynomial order & $(1)$ & $(2)$ & $(3)$ & $(4)$ & $(5)$ \\
\hline \hline & & & & & \\
Panel A: Cutoff at 18th birthday & & & & & \\
& & & & & \\
First & 0.000 & -0.180 & -0.180 & -0.018 & -0.018 \\
& $(0.000)$ & $(0.217)$ & $(0.217)$ & $(0.061)$ & $(0.061)$ \\
Second & 0.000 & -0.291 & -0.291 & 0.009 & 0.009 \\
& $(0.000)$ & $(0.544)$ & $(0.544)$ & $(0.406)$ & $(0.406)$
\end{tabular}

Panel B: Cutoff at 70th birthday

$\begin{array}{cccccc}\text { First } & 0.224 & 0.108 & 0.262 & 0.233 & 0.301 \\ & (0.255) & (0.201) & (0.157) & (0.123)^{*} & (0.121)^{* *} \\ \text { Second } & 0.268 & 0.366 & 0.085 & 0.174 & 0.099 \\ & (0.495) & (0.360) & (0.303) & (0.241) & (0.212) \\ \text { Bandwidth } & \pm 8 \text { mos. } & \pm 12 \text { mos. } & \pm 16 \text { mos. } & \pm 20 \text { mos. } & \pm 24 \text { mos. }\end{array}$

Notes: Notes: Each figure in the table is from a separate local regression with the specified bandwidth and polynomial. The dependent variable is an indicator which takes value 1 whenever the respondent says that Jornal Nacional is one of the three TV shows that he or she watches the most during the week. Panel A presents the results for those who were about to become 18 years old in October 2014. Panel B presents the results for those who were about to become 70 years old in October 2014. Sample consists of illiterate citizens who responded the Brazilian Media Survey at the years of 2013 and 2014. All standard errors are clustered on age measured in months and all regressions include survey year fixed-effects. Significance: *** $\mathrm{p}<0.01,{ }^{* *} \mathrm{p}<0.05,{ }^{*} \mathrm{p}<0.1$. 
Table A.9 - Placebo tests of exposure to abstention penalties on the consumption of Jornal Nacional around the 18th birthday cutoff.

\begin{tabular}{cccccc}
\hline Polynomial order & $(1)$ & $(2)$ & $(3)$ & $(4)$ & $(5)$ \\
\hline \hline \multirow{2}{*}{ Panel A: Cutoff at April 2013 } & & & & & \\
& & & & & \\
First & 0.037 & 0.037 & 0.016 & -0.007 & 0.004 \\
& $(0.042)$ & $(0.037)$ & $(0.037)$ & $(0.038)$ & $(0.031)$ \\
Second & 0.045 & 0.044 & 0.042 & 0.048 & 0.014 \\
& $(0.074)$ & $(0.042)$ & $(0.036)$ & $(0.040)$ & $(0.046)$
\end{tabular}

Panel B: Cutoff at October 2013

$\begin{array}{cccccc}\text { First } & -0.023 & 0.002 & -0.016 & -0.049 & -0.050 \\ & (0.048) & (0.038) & (0.033) & (0.028)^{*} & (0.027)^{*} \\ \text { Second } & 0.020 & -0.038 & 0.018 & 0.030 & -0.009 \\ & (0.077) & (0.068) & (0.045) & (0.043) & (0.045)\end{array}$

Panel C: Cutoff at April 2014

$\begin{array}{cccccc}\text { First } & -0.023 & -0.040 & -0.048 & -0.031 & -0.019 \\ & (0.034) & (0.025) & (0.028)^{*} & (0.028) & (0.027) \\ \text { Second } & -0.013 & -0.018 & -0.038 & -0.069 & -0.076 \\ & (0.058) & (0.044) & (0.032) & (0.027)^{* *} & (0.032)^{* *}\end{array}$

Panel D: Cutoff at April 2015

$\begin{array}{cccccc}\text { First } & 0.041 & 0.053 & 0.046 & 0.032 & 0.045 \\ & (0.074) & (0.056) & (0.049) & (0.047) & (0.043) \\ \text { Second } & 0.216 & 0.060 & 0.069 & 0.083 & 0.088 \\ & (0.099)^{* *} & (0.092) & (0.072) & (0.063) & (0.059)\end{array}$

Panel E: Cutoff at October 2015

$\begin{array}{cccccc}\text { First } & 0.008 & -0.003 & -0.077 & -0.057 & -0.050 \\ & (0.071) & (0.056) & (0.060) & (0.054) & (0.051) \\ \text { Second } & 0.330 & 0.079 & 0.054 & 0.015 & -0.007 \\ & (0.113)^{* *} & (0.067) & (0.059) & (0.064) & (0.062)\end{array}$

Bandwidth

8

12

16

20

24

Notes: Each figure in the table is from a separate local regression with the specified bandwidth and polynomial. The dependent variable is an indicator variable which takes value 1 whenever the respondent says that Jornal Nacional is one of the three TV shows that he or she watches the most during the week. Each panel presents the results for different months used as placebo cutoffs. Sample consists of literate citizens who responded the Brazilian Media Survey at the years of 2013 and 2014. All standard errors are clustered on age measured in months and all regressions include survey year fixed-effects. Significance: *** $\mathrm{p}<0.01,{ }^{* *} \mathrm{p}<0.05,{ }^{*} \mathrm{p}<0.1$. 
Table A.10 - Placebo tests of exposure to abstention penalties on the consumption of Jornal Nacional around the 70th birthday cutoff.

\begin{tabular}{cccccc}
\hline Polynomial order & $(1)$ & $(2)$ & $(3)$ & $(4)$ & $(5)$ \\
\hline \hline \multirow{2}{*}{ Panel A: Cutoff at April 2013 } & & & & & \\
& & & & & \\
First & -0.091 & 0.129 & 0.193 & 0.189 & 0.146 \\
& $(0.169)$ & $(0.163)$ & $(0.137)$ & $(0.120)$ & $(0.109)$ \\
Second & -0.209 & -0.005 & -0.004 & 0.081 & 0.141 \\
& $(0.362)$ & $(0.217)$ & $(0.202)$ & $(0.179)$ & $(0.162)$
\end{tabular}

Panel B: Cutoff at October 2013

$\begin{array}{cccccc}\text { First } & -0.235 & -0.129 & -0.156 & -0.036 & 0.021 \\ & (0.219) & (0.177) & (0.153) & (0.133) & (0.123) \\ \text { Second } & -0.194 & -0.233 & -0.178 & -0.225 & -0.207 \\ & (0.285) & (0.234) & (0.205) & (0.196) & (0.186)\end{array}$

Panel C: Cutoff at April 2014

\begin{tabular}{cccccc} 
First & -0.014 & -0.020 & -0.032 & -0.029 & 0.039 \\
\multirow{3}{*}{ Second } & $(0.223)$ & $(0.169)$ & $(0.136)$ & $(0.122)$ & $(0.109)$ \\
& -0.325 & -0.109 & -0.037 & -0.033 & -0.103 \\
& $(0.227)$ & $(0.281)$ & $(0.240)$ & $(0.197)$ & $(0.165)$
\end{tabular}

Panel D: Cutoff at April 2015

$\begin{array}{cccccc}\text { First } & 0.057 & 0.015 & -0.041 & -0.019 & -0.004 \\ & (0.127) & (0.111) & (0.108) & (0.089) & (0.084) \\ \text { Second } & 0.317 & 0.062 & 0.060 & -0.031 & -0.020 \\ & (0.207) & (0.139) & (0.128) & (0.131) & (0.121)\end{array}$

Panel E: Cutoff at October 2015

$\begin{array}{cccccc}\text { First } & -0.057 & -0.007 & 0.011 & -0.013 & -0.007 \\ & (0.112) & (0.094) & (0.075) & (0.069) & (0.067) \\ \text { Second } & 0.189 & 0.018 & -0.022 & -0.017 & -0.033 \\ & (0.123) & (0.113) & (0.123) & (0.107) & (0.099) \\ \text { Bandwidth } & \pm 8 \text { mos. } & \pm 12 \text { mos. } & \pm 16 \text { mos. } & \pm 20 \text { mos. } & \pm 24 \text { mos. }\end{array}$

Notes: Each figure in the table is from a separate local regression with the specified bandwidth and polynomial. The dependent variable is an indicator variable which takes value 1 whenever the respondent says that Jornal Nacional is one of the three TV shows that he or she watches the most during the week. Each panel presents the results for different months used as placebo cutoffs. Sample consists of literate citizens who responded the Brazilian Media Survey at the years of 2013 and 2014. All standard errors are clustered on age measured in months and all regressions include survey year fixed-effects. Significance: ${ }^{* * *} \mathrm{p}<0.01,{ }^{* *} \mathrm{p}<0.05,{ }^{*} \mathrm{p}<0.1$. 